 \\ ERDÉLYI TUDOMÁNYOS FÜZETEK

A ROMÁN TÖRTÉNETTUDOMÁNY ÉS A SZÉKELYFÖLDI ROMÁNSÁG KÉRDÉSE

IRTA

- TÓTH ZOLTÁN

AZ ERDELYI MUZZUM-EGYESULET KIADASA KOLOZSVAR, 1942 
Különlenyomat

az ERDELYI MÚZEUM

1942. évi 4. számából
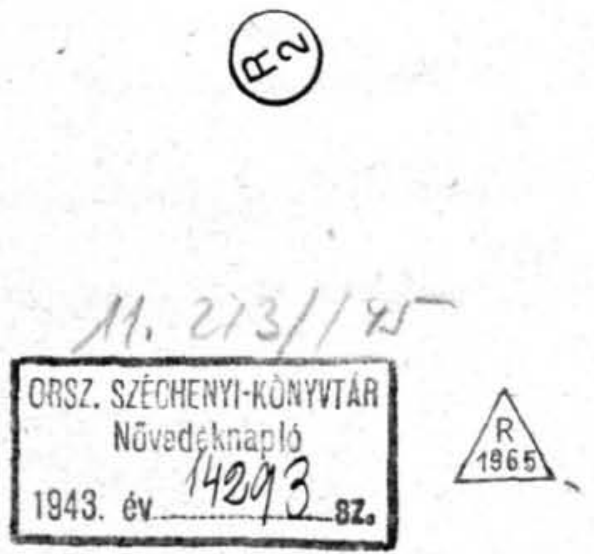


\section{A román történettudomány és a székelyföldi románság kérdése}

1.

A székelyek részleges román származásának tanát Iorga Miklós tette közismertté. ${ }^{1}$ Páratlan tekintélyével, nagyhangú fellépésével, fényes, de hamis érvelésével a nagyhírü román tudós kérdéssé tudott tenni egy egyszerü ötletet, ${ }^{2}$ amellyel nemzete érdekeit akarta szolgálni. Sok ideig, több rnint egy évtizedig tartott, amig tanitásának visszhang.ja támadt.

Az elsö világháború elött sem Erdélyben, sem az ókirályságban igazi székely-román kérdés nem létezett. Erdélyben már azért sem, mert a szétszórt székelyföldi románság minden szempontból, anyagilag és szellemileg clyan gyöngének mutatkozott a szilárd tömbként tömörülö, erös nemzeti öntudatú székelység mellett, hogy az erdélyi románság alig merte volna remélni, lıogy e tájon valaha is felvirágozzék. A Székelyföld mind a magyar, mind a román közvélemény elött mint fajtiszta lakosságú és magyar jellegü terület volt ismeretes. Az adott politikai viszonyok sem engedték meg, hogy a szórványban élö székelyföldi románok öntudatban ellanyhulva, a beolvadás ellen nem is, vagy alig védekezve, komoly és reménykeltö nemzeti nunkába fogjanak. Az erdélyi románság részéröl a görög katolikus egyház volt leginkább érdekelve, de ez sem tett érdemesebb lépéseket román szem. pontból székelyföldi hitsorsosai érdekében. A régebbi román történetírók, igy Xenopol sem tudtak semmit a románok beolvadásáról a székelységbe. Nem csodálkozhatunk rajta, hogy magyar részröl sem merült fel ilven kérdès komoly formában. Egy-két helyi körülményekböl kinött sajtóközleményen $^{3}$ kívül semmi sem mutat arra, hogy a magyarok a Székelyföldön lakó románok, vagy román valláson lévök dolgát komoly kérdésnek ítélték volna. A románok a székelyföldi beolvadás mögött elöszeretettel szinte ördögien mesteri rendezésü központi elgondolást és kifogástalan kivitelt látnak. Jellemzö ennek a felfogásnak a tévességére, hogv a székelység ügyeit nagy részletességgel letárgyaló csíktusnádi székely nagygyülésen még

1 L. tölım: Iorga Miklós és a székelyek român származásának tana. EM. 1941:265-81.

2 Valószinü, hogy Iorga ötlótét Weigand Gusztávnak, a híres lipeaei romanistának egy cikke is ihlette (Die Dialekte der Moldau und der Dobrudscha. Jber. d. Inst. f. rumän. Sprache. Leipz. IX (1902), 138). Weigand a Székelyfölanek majdnem ugyanart a részét járta be, mint késöbb Iorga. A románsíg itt szerinte a múltban jelentös tömegü lehetett, de a székelységnek nem tudott ellentállni. Ma kifejezetten sqékely jellegü köz:ségekben a lakosság román származású. Háromszéken 120 ezer magyar mellett 30 ezer románról tud, ezekből mintegy 5 ezer teliesen elmagvarosodott.

3 Alföld (Arad), 1862. okt. 17.; Ellenzêk, 1882. nov. 28.; 1895, febr, 8; 1901. dee. 4 , stb. 
csak szó scm esett a székelyföldi románok beolvasztásáról. ${ }^{4}$. Még álmában sem jutott senkinek sem eszébe, hogy a székelység román eredetének, ragy erős kevertségének, még kevésbbé elrománositásának kérdésével foglalkozzék. A román kérdést Janesó Benedek megpróbálta beledobni a magyar közréleményhe, mégis, felette kevesen tartották valószínủnek, hogy a balkáni jellegünek ismert, katonailag aránylag gyenge Románia olyan külpolitikai helyzetbe kerülhessen, hogy az erdélvi román kérdést a magvarságra nézve végzeles kimenetelüvé tehesse.

Az 1910-es évek tájáin a helyzet kezdett megváltozni. A hajdudorogi magyar szertartású görög katolikus püspökség felállitása nagy mértékben kiélezte a helyzetet a magyarság és a románság közt. Az utóbbi feléhredt felelösségérzettel a már-már teljesen feladott székelyföldi görög katolikusság iránt, faji szempontból kezdle tekinteni azt a 35 egylázközséget, amelyet az új rend magyar egyházi föség alá helyezett volna. Panaszait röpirataiban éppen Iorga közvetitette Nyugat felé. ${ }^{5}$ A világháború küszöbére tehát a székely-román kérdés idöszerüré vált. Amig a háhorú tartoll, a kérdés román szemponlú lehetöségei természetszerüleg csak csökkenhettek. Lényegesen megváltozott a helvzet a monarchia összeomlásával. Ettöl kezdve a védekezöböl lett a támadó. Maga a székelyföldi görög katolikusság nagy része nem lekintette magát ckkor sem románnak, a többi pedig nem képviselt nagy tömeget, lehát cröt. A lámadó szerepet ezért legelöször nem is a helyi román elemek vettèk fel. A változásnak természetesen a kérdés tudományos megitélésében is meg kellett nỵilvámulnia. Mintha az idök Iorga álmait igazolták volna.

A románoknak székelyföldi ösiségét és a székely vérnek a románnal való erös keveredését Iorga Miklós kitarłó szorgalommal hirdette, tanította, népszerüsítette. ${ }^{6} \mathrm{Az}$ elhintett mag eleinte elég nehezen fogant meg, végül mégis szárba szökkent. A következökben ismertetni fogom lorga ötletének elterebélyesedését a román tudományos életben.

Azok közül, akik a világháború legvégén a székelyek jövendö sorsával román részröl foglalkoztak, emlékezzünk meg arról a Lăpĕdatu Sándorról, aki a világküzdelem alalt Iorgának kitünëen bevall munkatársa, a béketárgyaláson pedig mint hivatalos megbizolt a román bizonyító anyag egy tekintélyes részének szerkesztöje volt. ${ }^{7}$ A székely kérdés elötte már nem elméleti síkon jelentkezett, mint Iorgánál, célja egészen gyakorlati voit:

4 A hivatalos határozati javaslat szerint a r. k. egyházi ügyek elö̊dojának, ,különös tekintettel“ kellett volna leunie a ,görög katolikus székelyekre“. Sokatmondo, hogy ezzel sem az elöadói elöterjesztésben, sem a részletes tárgyaláson nem tartották szükségesnek érdemlegesen foglalkozni (SzEkely kongresszus. A kongr. helye, ideje stb. Bp. 1902, 58 és A szék. kongr. szervezete stb. Bp. 1902, 526-7.).

Bue. 1913.

б L'évêché de Hajłu-Dorogh et les droits de l'église roumaine mie de Hongrie.

- A román nép számára irt és Erdélyben szélesłörüen elterjedt román történetében (Istoria Romînilor pentru poporul romînesc. Vülenii-de-M. 1908) \{́rja: „....sokan a székelyek közül román származásúak; amint mi elnemzetietlenítettük a Vaskapú melletti és a Hátszeg viáki magyarokat, úgy a magyarok elnemzetietlenitettek bennünket ama keleti részeken" $(32-3)$. Népies tört'́netéböl alakitotta át középiskolai használatra szánt. sok kiadast megért román történetét. Természetesen ebböl sem maradt ki a székely-kêrdés.

${ }^{7}$ L. Cräciun könysészeti összefoglalását: Fraților Alexandru si lon I. Luăpèdatu la implinirea vârstei de 60 de ani. Pue. 1936, XLII-XLIII. 
bebizonyitani a béketárgyalóknak, hogy a Székelyföld tömör népi egysége nem lehet akadálya Erdély Romániához raló csatolásának. Munkája elóször Iorga Iașiba menekuilt lapjäban jelent meg. ${ }^{\searrow}$ Felfogása szerint a szćkelyek, akárcsak a balkáni arománok, annyira idegen népek közé ékelve élnek, hogy semmi reményïk sem lehet az elkövetkezó elrendezéshen faitestréreik. kel egy államot alkotni. „Megfosztva egy külön, független gazdasági és politikai élet megalapozásának eszközeitöl, arra vannak ítélve e szempontból, hogy alárendeljẻk magukat annak a népi tömegnek, amelynek közepére öket a sors odadobta." A székelység a multban a románokkal gazdaságilag és földrajzilag egyetlen életegységet kípezett, s ezt csak a kiegyezés zavarta meg mesterségesen. Gazdasági téren a székely nép nem képes megélni, politikai kïlönállásra, államalkotassa nincs módja. „A széknly kérdés megoldása tehát csak egy lehet: ... a jüvendö román politikai szervezetbe való belefoglalása, müvelődési és közigazgatási önkormányzat, melynek rendeltetése külön politikai élete megörzése és kifejlesztése...; önkormányzat, amelyet a szóban forgó eselben a románok lesznek legelsök elfogadni és tiszteletben tartani", hiszen a kicsiny, alig 4-500 ezernyi szckely tömb „,sohasem fog valamely komolyabb hátrányt képezni a román nép nemzeti és politikai életében." "io

Meglepö, hogy Iorga bizalmasa, aki mesterének a székelyekre vonatkozó tanulmányait munkảja megszerkesztésében felhasználta, ${ }^{11}$ komolyabb birálói érzékkel rendelkezelt és aránylag kevéssé eselt áldozatául a nagy román történetíró túlzásainak. $O$ is beszél ugyan elsikkasztott románokról $1^{12}$ és ,megjavitja“" az 1910-i magyar hivatalos népszámlálás eredményeit, ${ }^{12}$ de inkább a hajdudorogi püspökség "felháboritó visszaélése" váltja ki nemzeli érzékenységét. ${ }^{14}$ Még inkább meglepö felfogása a székely kérdésnek müvelödésí és közigazgatási önkormainyzat formájában elképzell megoldásáról; ez engedékenységben lényegesen túlment a béketárgyaláson Romániára a szó legszorosabb értelmében ráeröszakolt kisebbségi egyezmény müvelödési és iskolaügyi önkormányzałának mindiă elméleti sikon maradt követelményén. Alláspontja az erdélyi román nemzetiségi korszak tanulságainak becsületes alkalmazásán alapult és ugyanabból a hamarosan kioltott lélekböl fakadt, mint a gyulafehérvári nemzetgyülés híres határozatai. Lăpĕdatu a jánlata a székely kérdés megoldására a diadalittas román vezetök és közvélemény elött magától értetơdöen korszerütlemnek bizonyult. ${ }^{15}$

A székely kérdésre Lăpëdatu egv brassói elöadásában újra visszatért. Iorga kutatásai alapjản hangsúlyozza a székelyek és a románok zavartalan jóviszonyát az elmult századok alatt. A székelyek szerinte ösztönösen mindig

\& Problenta săcuiască. Neamul Românesc, 1918. nov. 3., késöbb közölve a Miscellanue címü kötetébeu (Buc. 1925.), innen idózem.

I. m. 161.

10 I. m. 162 .

11 Különösen: Acto româneşti din Ardeal privitoare în cea mai maro parte la legăturile Secuilor cu Moldova. B. Com. Ist. a Ron. II, 1916, 179-272.

12 "Românii mistificați priutre Săcui“. 160.

13 Szerinte a székelỵföldi románok arányszáma 16,1\% . (160). Az 1910-i népszámlálús szerint $15,5 \%$.

16 Uo.

15 Cikkét 1925-ben raltozatlanul újra lenyomatta. Vö. fentebb 8. jegyzot. 
érezték alárendeltségüiket a román nép életével szemben és innen van az, hogy a történelem nem jegyez fel egyetlen huzamo:abb politikai vagy katonai összeütközést sem küztük és az erdélyi románok, vagy akár köztük és a havaselvi vagy moldıai románok közt, söt azt lehet mondani, hogy a viszony között egyenesen ,baráti volt. ${ }^{16} \mathrm{Az} 1867$-i kiegyezés a székelyeket hagyományaik és gazdasági érdekeik ellenére való életre kényszeritette. Lăpědatu meggyözödése, hogy a székelyek magyar nemzetiségi érzése mesterséges politikai nevelmény és azt barátságos román magatartással ki lehet kü:zöbölni. ,Akkor semmi sem fogja megakadályozni a két nép jóviszonyát és összetarlását. Mert a román népnek nincs szüksége magát románosító politikával fenntartani egy olvan néppel szemben, amely nem lesz irredenta és hü lesz a hazához. Nem fogja azt a politikát folytatni. mert elegen vagyunk - írja Lăpědatu - és nincs szükségünk elnemzetietlenitett székelyekre, mert a multból megtanultuk, mire mennek az ilyen politikára alapozott államok..."17 A székelyt és a magyart nemzetileg külön szakasztani Lăpĕdatu számára képzelgés volt, de mint ,kisebbségi " lelkületü ember nem volt képes Iorga hagyományának szolgájává szegödni: lemondott : „,visszarománosítás“" történelmietlen és igaztalan ürügvéröl.

\section{2.}

A Iorga megkezdette irányt - többé-kevésbbé tudományos módszerek alkalmazásával - egjelöre mások fejlesztik tovább. Bármennyire is öví volt a gondolat, neki nem volt türelme alapos és aprólékos részletkutatással helehatolni az ismeretlen mult homálvába, inkábh inluiciójában hizott. Szeszélyes és lendüleles, de megbízhatatlan vérmérsékletétöl sarkalva, itt-ott rávillan szeme a kérdés valamelyik ágára, de igazán komoly történelmi munka nem kerül ki a tolla alól. Kisebb jelentöségü tudósok, a román föld és mult szorgalmas és rajongó kutatói, nemzeti érzésüktöl hevitve új érveket kovácsolnak, új adatokat gyüjtenek a román fajta székelyföldi hódító hadjárata számára. Ez a kutató nemzedék fájlalja, hogy ,,a székely sziget természetellenes módon ... megszakitja a román tenger folytonosságát". Ezért, ,az uralkodó román nemzeti elem szemmellátható eltünése aránylag kiterjedt tartományban“ — „elsörendü történelmi és földrajzi kérdés." Így jellemzi a székely kérdést 1922-ben a román középiskolai töldrajztanárok brassói gyülésén Mihăilescu Vintilă, Mehedinţi Simon buka . resli egyetemi tanár tanársegéde. ${ }^{18}$

Mihăilescu mindenek elött a Székelyföld földrajzi egységét veszi tagadóba azzal az állításával, hogy a multban a Hargita néptelen magaslata sokkal jelentősebb életföldrajzi válaszfal volt, mint maga a Kárpátok

16 Săcuii și Românii. 1924. máre. 16. Miscellanae, 95-6.

17 I. m. $97-8$.

18 Câteva observaţii asupra Românilor din Secuime. B. Soc. Reg. Rom. de Geog:. XLI, 1922, 112. Maga Mehedinţi is korán felfigyelt a székely kérdésre [Vö. brassói elö. adását: Vechimea poporului român şi legătura cu elementele alogene. Buc. 1925. - A renegát Ébert András tanår a székelyudiarhelyi román liceum elsö értesítöjében (1924) összefoglalóan foglalkozik a székely-román kérdéssel, teljesen román beállitásbnn. R(sz-. letek belöle: Secuimea (Székellyudvarheìy), 1932. máj. 28.]. 
Iögerince a székelység és a moldvai románság közt. A kárpátközi mélyedéseket, Csiktól a Barcaságig, csak a székelység Udvarhely környéki eröközpontja elöteréül tekinti. Komolyabb keletröl jövö támadást szerinte csak a Hargita vonalán lehetett volna kirédeni. Vagvis a moldvai határ valójában inkább a Hargitán volt; igy volt lehetséges, hogy a moldvai románság részben „megmaradhatott" a Székelyföld keleti peremének egyes darabjain. Mint lorga és Lăpĕdatu, ö is kihangsúlyozza a székelyek barátságos magatartását a románok iránt. Mihăilescu elismeri, hogy Európa megvédését kelet támadásaival szemben a kezdetleges szervezetü románság nem, csak a katonailag hatalmas magyar apostoli királyság vállalhatta magára a müvelt világ eme legelöretoltabb bástyáján. Ezzel szemben a székelyek müveltségét a románoktól nyert „trák-római“, vagy ,trák-rómaiszláv" kultúrából eredezteti, mert a románság be nem igazolt ösi székelyföldi jelenlétét a székelység letelepülése elött valami érdemmel fel kellett diszitenie. ${ }^{19}$ „Majdnem felesleges még (!) bizonyítékokat felhozni a románok hamarábbi jelenlétére Erdély keleti vidékein" - mondja Mihăilescu, mert a románság folytonossága a Székelyföldre kiterjedöleg is „földrajzi és néprajzi szükségszerüség“. Néhány helynevet (mint pl. „Bogdán-hegy) és a két Oláhfalı esetét emlegeti bizonyságképen és sürgeti a helynévkutatás meg. indítását, a ,román és székely müveltség közti nyilvánvaló hasonlóság" tanulmánvozását, az embertani közösség kimutatását. Túlmenve Lăpědatu már ,,javított" statisztikáián. 1900 körül a Székelyföld lakosságának $23 \%$-át tes>i meg román rérségünek. „A székelvség alapja tehát - igv hangzik következtetése - a román vér és a régi trák-római-szláv műveltség.“20

A földrajzi érv mellett a székely élet összehasonl’tó tanulmányozása szomszédaival, a szásszal és a románnal, fog nagyobh rilágosságot árasztoni. Addig is ,,a keveredès a román néppel és ennek korábbi jelenléte (preexistental a székely tertományban igazolt ténynek tekinthetök". A magvar és a székely eredetileg lehetett egy nép: ma már nem az. ,A népi altalai, amelyre a kiváltságos telepesek támaszkodt: $\mathrm{k}$, valamint a fizikai környezet huzamos gazdasági és politikai táji (regionális) hatása módosította a jövevények tulajdon`ágait és új népi t'pust alkotott."21

Mihăilescu tehát kikezdi a Székelyföld földrajzi egységét, megtámadja a székely nép faji egységét és tagadja magyar jellegét. Bizonyitó eljárása - láttuk - ingatag, de azok számára, akik számára ezek az érvek szólnak, elég erösek, mert meg akarnak gyözetni. Így lesznek Iorga továbbfejle`ztett érvei alkalmas eszközzé egy hód’tói kedvében logikailag kevéssé érzékeny nemzeti közvélemény megnyerésére.

Amint láttuk, a háború elött és alatt szenvedölegesen viselkedö romån közvélemény a háhorú után épen megforditva kezdett viselkedni. Védekezc̈böl támadó lett és ez az ùj magatartás tükrözödik vissza a székelyromán kérdésre vonatkozó román tudományos munkákból is. Mihăilescu

18 Mihăileseu, i. m. 112-5.

20 I. m. $116-7$.

${ }^{21}$ I. m. 117-8. Vö. Mihăilesou késöi válaszát Szádeczky Lajos A székelyek oláh rokonságának meséje. Bp. 1926 címü cikkére: Dr. Lajos Szádeczki şi problema seouiască. B. Soc. Reg. Rom. de Geogr. XLIX, 1930, 127-139. (Románul és frantiául.) 
nem volt az utolsó azok közül, akik a székelység ellen inditotl támadás lebonyolításához fegyvereket szolgáltattak.

A támadás központja - eleinte - a kolozsvári román egyetem letl. Egyes intézetei, a földrajzi, történeti és az egészségtani intézetek belekapcsolódtak a bizonyitási aljárásba; ennek célja a székelység magyarságának kétségbevonása és románsảgának bizonyítása. A földrajzi intézetben Vàlsan György egyetemi tanár vezetése alatt már 1920-tól kezdve készitenck a hallgatók kisebb monográfiákat, lehetöleg szülöföldjükröl. A jobb tanulmányokat az intézet kiadványa, a ,Lucrările Institutului de Geografie" volt hivatva közölni. Vâlsan öntudatosan törekedelt a középiskolákbauı eihanyagolt földrajzi és néprajzi kérdéseknek ludatosítására minél szélesebh társadalmi rétegek közt. Mint Iorga már 1902-ben a „,Sate şi preofi“ cimü müvében, éppen úgy. Válsan is fel akarta dolgoztatni minden román település monográfiáját, hogy azután ezeket nagyobb tájmonográfiákba foglalhassák üssze. ${ }^{22}$ Ilyen nagyméretü munkát csak közösségileg, értelmesebb vidéki lanítók ès papok segítségével lehetett volna elvégeztetni. Terve csak részben vałósult meg, mégis utóda Meruţiu Viktor 1938-ban közel 300 egyetemi hallgatóktól készítelt tájmonográfiát számolhatolt elö. ${ }^{23}$ Vâlsan érdeme, hogy a népi értékekre hivta fel az erdélyi románok figyelmél, ebben látva mes népe igazi erejét és jövöjének biztonságát. Irodalmi téren a román föld és nép egységének bizonyitására törekedett. ${ }^{*}$ A Vàlsan megszabta irinyı követte szerényebb képességgel Meruţiu is.

Az új iskola vonala nagyjából megfelel a Iorga-Mihăilescu megvont: iránynak. Elsö jelentösebb terméke Vàlsan tanitványának. Opreanu Szabinnak tolla alól került ki. Elöször egy kolozsvári új és friss szellemü, a nemzetitársadalmi kérdésekkel foglalkozó folvóiratban, a Societatea de mâine-ben közölte a székelyföld egy darabjáról irt lanulmányảt, ${ }^{25}$ majd kötetecske formájában is megjelentette ,Terra Siculorum“ cimen. ${ }^{2 C}$ Udvarhely vármegye népiségtörténetével és népességrajzával foglalkozik benne nem éppen a legkorszerübb módszerek alapján. Sem levéltári kutatás, sem módszeres hely- és személynévkutatás nem támogatta állitásaihan. Megelégedett a kiadott és gyakran másodkézböl vett okleveles anyag egy részének felïletes. hiányos és célzatos vizsgálatával. Gvakorlati célkitüzéseit nem is igen igyekezett elrejteni. „E kérdések újrafelvételének ma kettös fontossága van: elöször tiszta tudományos szempontból, azután gyakorlati-politikai szem. pontból. Az érintett kérdésre vonakozó igazság megállapitásából hizonyos müvelödési-politikai ternészetü rendszabályoknak kell következniök, amelyek képesek legyenek biztositani a legközelebbi jövöben a helves egven súly visszaállítását a népek megoszlásában a Hargita körül, ahol ma Ro-

"2 Vâlsan bevezetése Opreanu S. Sŭcuizarea Românilor prin religie (Chuj, 1927) címü füzetéhez. I-V.

${ }^{23}$ Luerările Inst. de Geogr. VI (1938), 303-59.

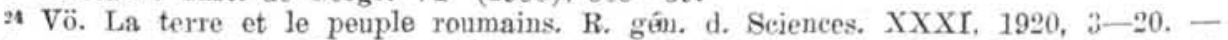
Transilvania in eadrul unitar al pământului și Statului român. Transilvania, Banatul, Crişana, Maramureşul. Bue. 1929, I, 145-56. - Conștiința națională şi Geografie. Buc. 1921.

${ }_{25}$ I, $1924,725-7$, II, $1925,12-4,42-4$.

26 Terra Siculorum. Contribuțiuni privitoare la Românii din ţinutul Săeuilor. Cluj, 1925. 471 . 
mánia legtömörebb kisebbségi népe, a székely lakik." A szerzö azért választotta rizsgálata tárgyául a legszékelyebb megyét, mert ,ha sikerül megállapítani legalább részben a történelmi igazságot a szék román népességét illetöen, annál könnyebb lesz ez a dolog Felsö-Dácia többi kisebbséglakta tartományában" ${ }^{\prime 2}{ }^{2 i}$

Opreanu feltevése az, hogy az erdélyi régekre a magyar királyoktól határt védeni kitelepitett valódi székelyek román, közelebbröl szláv-román rétegekre telepedtek rá és ezeket rövidesen magukba olvasztották. Ez a folyamat nem erőszakkal történhetett; a vonzóerő a székely nép kiváltságos jogállásában rejlett. A folyamat legkésöbben a XV. században lezárult. ${ }^{28}$ A román nép jelenlétének bizonyítására itt csak azt az állítását tudja felhozni, hogy a székelyek manapság sok román ronást árulnak el. „Csak̄ ha egy nép egy másikkal egybeolvad, hágv olyan mély nyomokat a társadalmi, politikai életben, nyelvben, öltözékben, foglalkozásban és szokásokban, amint ezt a románoktól kölcsönzötten a székelyeknél látjuk."29 A szerző érzi érvelésének ingatag voltát, ezért történelmi forrásokat próbál tétele érdekében megszólaltatni. Már az elmondottakból kitünik, hogy a bizonyitási folyamat nem a tényekböl kiindulva érkezik el egy itéletig, hanem éppen megfordítva, egy politikai-gyakorlati célú tételtöl visszafelé halad a valószerüség látszatát keltö ürügyekhez. İgy talál rá két XIV. századi adatra, hogy ezek félreértése révén a székelyföldi románság jelentöségét, régiségét és számarányát mérték nélkül eltúlozza.

Az elsö László (Vencel) király egy kiváltságlevele az oláhfalusi románok számára (1301). Az oklevél tartalmán jóval túlmènöen román többségü lakosság jelenlétére következlet, söt ennek még arányszámát is, teljesen önkényesen, 40 \% -ban állepítja meg: „hozzáretöleges arányszám, amelyet a románok javára fel lehet emelni" ${ }^{30}$ Az oklevélról azonban Karácsonvi János már régen kimutatta, hogy hamisitvány, gróf Kemény József XIX. századbeli koholmánya. ${ }^{31}$

27 I. $m .4-5$.

${ }_{28}$ I. m. 19. - Opreanu bizonytalan ebben az allitásában, azért még hozzáteszi: „Természetesen ezt esak általánosságban lehet állítani. Elszórtan fennmaradhattak késöbb is kis ösromán szigetek" (20. 1.).

20 I. m. 20 ,

30 I. m. 5-13. A kiváltságlevelet 1. Szék. Okl. I, 29-31.

${ }^{3} \mathrm{Az}$ oklevél késöi, legalább XVIII. századi latinsággal ran megírva (Karácsonyi János: Pótlások a hamis, hibáskeltü és keltezetlen oklevelek jegyzêkéhez. Tört. Tár 1908, 30-1. - Miiller G.: Mitteilnngen d. Inst. f. öst. Geschichtsforsehung. 1915, 403). Karácsonyi azt is kimutatta, hogy az olahfalusiak Vencelhez fordulása szeptember elején (az aug. 27. én megkoronázott királyhnz!) az akkori körülmények közt tér és idöbeli lehetetlenség. Ezenfelül Erdély nem is volt Vencel pártján [Karácsonyi: Sabin Opreanu a hamisitó kelepcéjében. Magyar Kisebbség I (1925), 222]. Karácsonyi szerint Oláhfalut Báthory István telepíthette le 1480 táịan. A falu neve oklevelesen a XVI. sz. elött nem. is fordul elö. A falu nevét kétségtelen̄ell a körnvék székelv lakossága adhatta a betelepülö oláhokról. I. m. 224. Az Erdélyi Nemzeti Múzeum Levéltára birtokába került 18 darab XVE, százađi levél már tiszta magrar lakosságról tanúskodik (Jakó Zsigmond szíres közlése). Vö. még Fekete-Nagy-Makkai: Documenta Valachorum, 45. 1. 2. jegyzet. Megjegv7endo, hogy Onreanu az $1301 \mathrm{i}$ oklerelet, épúgy mint a nápai tizediegyzéket másod-

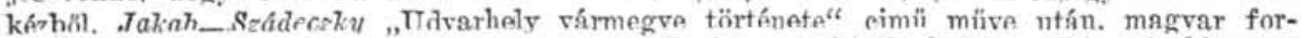
dításból használta. Bár tudomást szerzett Karácsonyi bírálatáról, továbbra is kitartott téves álláspontja mellett. 
Másik adatnak az 1332-37-bỏl ránkmaradt pápai tizedjegyzékeket tekinti, ${ }^{32}$ teljesen indokolatlanul, mert a jegyzékekben egyetlen helynév emlékeztet román lakosságra, ez is kiviil esik a Székelyföldön. ${ }^{33}$

Opreanunak nem volt könnyü dolga, amikor székely területen a középkorban vagy az újkor elején románokat keresett, a források ugyanis hallgatnak róluk. Ezért kénytelen rolt más megoldáshoz folvamodni. Az elöforduló jobbágy kifejezést minden torábbi nélkül románnak értelmezi. ${ }^{34}$ Az 1614.i lustrumban szereplö 501 ösi jobbágyot (iobagiones antiqui) román öslakosságnak nyilvánitja. ${ }^{35}$ Ugyanígy tesz 1711-ben az „ős adózó jobhágyok"-kal., ${ }^{36}$ Tény, hogy az ösjobbágyok közt vollak románok is, de valamennyit románnak tekinteni több, mint túlzás A székely társadalom a XV. század végén olyan fokú rétegeződést mutatott. amely a rendi átalakulást elösegítette. A XVI. század elejére az adózó tömegeknek sokrétü tömege alakult ki, s ebböl a század második felében, János Zsiğmond uralkodása alatt igazi jobbágvréteg fejlödhetett $\mathrm{ki}^{37} \mathrm{~A}$ rendi átalakulás fokozatosan haladt elöre és repesztette széjjel az ősi székelv társadılmi és politikai szervezetet. A keletkezett résekbe a románság most már hevándorlás útján könnven heférközhetett, hiszen a jobhágy-igába szoritott önérzetes këzszékelvekkel az adományos birtokosoknak rengeteg bajuk volt. m’g a jörexény románság. akár Frdéluből, akár a fejedelmśngekhöl jëft lógven. a inhhágvi álle potot aránvlag sz'vesen vállalta, mert móọ ez emelkedóst ielentett számára A románság ielenlétével a $S_{7}$ kolvfüldän már a XV. században stámolni lehet. Frre vall Pereck és nlóhfalu esete. ${ }^{38}$

Valóban. a Bucov-féle összeírás $(17 f 0)$ Udvarhelyszék maidnem minden közcégében (102 közül 99-ben) talált románnkat, illetöleg román vallású lakosckat. de az is igaz, hogy csak elenyészö számaránvhan. A legtëbh helrsćghen $1-2$. néhol $10-20$ és csik 8 faluban volt több 20 román felekezetű esaládnál. ${ }^{39} \mathrm{Ha}$ ezeket mind románoknak vesszük, perị ez minden körülmények közt túlzás volna, az udvarhelyi románok számát a fenti adatok alı́pján nem vehetjük jelentékenvnek. 1767-ben, amikor a rendi fejlödés társadalmi és gazdasági téren már mélven bebatolt a székelvség régi törzsi-kıłonai szervezetéhe, az erdélvi kancelláriának egv ađóïgci tájékoztatás céljából készült táblázatos kimutatása (ez a társadalmi tényezỏket és nem a nemzetiségi viszonyokat tünteti fel!) a régi, sokáig egységes-

${ }^{32}$ I. m. 13.

3s Oláhfenes (Kolozs m.). Theiner A.: Mon. Vat. Hung. Rationes collectorum Pontif. in Hung. Bp. 1887. S. I. t. 1. 94, 103, 119, 139. - Mint az elsö ismert székelyföldi román helységnévre Opreanu „Zokaloka"-ra hivatkozik (Contrib. la topon. din țin. Săc. Lurer. Inst. de Geogr. al Univ. din Cluj. II, 1924-25, 179). A lok =lak, lakás szót egyformánhangzás alapján tévesen a román loc $=$ hely szóból értelmezi.

34 Terra Sic. 23.

ss I. m. 15. Vö. Jakab-Szádeczky: Udvarhely várm. tört. Bp. 1901, 332.

3s Szék. Okl. VII, 160.

37 Lóránd Lajos: A székely jobbágyság kialakulása. 1540-1571. Bp. 1906, 3-4, 6, 32-3, 46, 56. - Szádeczky L.: A székely nemzet történelme és alkotmánya. Bp. 1927, 52 kk.

38 Bereck: 1426. Szék. Okl. I, 121.

80 Nagygalambfalva 45, Boldogasszonyfalva 30. Homoródalmás 29, Bözöđújfalu 27, Vargyas 24, Gagy 23, Bögöz 23, Keresztúrfalva 22 román esaláddal. Jakab-Szádeczky: i. m. 479 , 2. jegyzet. 
nek hitt székely nemzet képét teljes bomlásban és a rendi keretbe való átrétegezëdésben mutatja be. Föként a szabad székelyek (liberi Siculi) száma csappant meg végzetesen, mely azelött a székely nemzet zömét tette ki. A közszékely családok száma (7866) kevesebb a primipilus családokénál (8692). Ellenben a jobbágy és zsellércsaládok száma (10.722, illetöleg $3655)$ éppen a közszékelyek lesüllyedt rétegével duzzadt fel oly hatalmasan, hogy végeredményben a nemzetnek már több mint fele az új, rendi, társadalmi rétegekben helyezkedett el. ${ }^{40} \mathrm{~A}$ társadalmi átrendezödésnek ebben az állıpotában, mely més a XV. században elkezdödött, a románság s7ámára is volt hely. Az 1761-böl és 1767-böl származó adatok hozzávetöleges tájekozást nyújtanak számukról. Az elsö azt mutatja, hogy az udvarhelyszéki románok elszórtan, jelentösebb társadalmi összefogás nélkül éltek a székely tömegek közepette, ahol természetesen társadalmi helyzetük a legalacsonyabb volt. Mindössze pópáik gondoskodtak - úgy-ahogy vallásos összefogásukról és gondozásukról. ${ }^{41} \mathrm{Mi}$ sem természetesebb, hogy ez az idegen, kóborlásra és helyváltozásra hajlamos, talajtalan és csekély. számú népréteg nem játszhatott szerepet a Székelyföld közéletében, aminthogy azt a sokkal számosabb és gyökeresebb vármegyei románság sem tehette meg a adott társadalmi-politikai viszonyok közt. De a román jobŁágy- és pásztornép száma a rendi átalakulással egy ütemben szaporodhatott és valószínü, hngy Udvarhelyszékben jórészt Erdély, esetleg Havaselve területéröl került ki. ${ }^{42}$ A csíki és háromszéki románok nagyobbrészt moldvai jövevények voltak, akik egyházi kapcsolataikat a Kárpátokon túllal még sokáig fenntartották. ${ }^{43} \mathrm{Az}$ új székelvföldi földesúri osztálv természetesen kapva-kapott a jövevény románság ingyenes munkaerején. ${ }^{44} \mathrm{~A}$ románság beszivárgása nem tömegesen, hanem egyénenkint, esetleg családonkint, tehát feltünés nélkül történt. Így alakult ki egy vékony és teljesen szétszórt jövevény román réteg a Székelyföldön, melynek ezen a vidéken semmi gyökere és ösisége nem rolt. Alacsony társadalmi helyzete, müvelet. lensége és politikai jogtalansága miatt nemzeti értelemben vett fejlődéséröl szó sem lehetett. Ennek azonban nem valami nemzeti jellegü elnyomás, hanem a kor rendi értelmü gondolkodása és szervezete és a táj eredendő magyar jellegü székely népességének uralkodó volta és többsége az oka. De nem is lehettek ennek a románságnak nemzeti igénvei sem; gvökértelen lévén anyagilag és szellemileg, hiszen pópái is teljesen müveletlenek voltak, nagvon hamar, minden kényszer nélkül elindult a beolvadás útián, elöször nyelvileg. azután vallásilag. Az ortodox, keleti életforma lehetett a legnagvobb akadálva a heolvadásnak, de a románság vallási uniója 1700 körül ezen a téren is megkönnyitette az utat a a római katolikus magyar egyház felé. ${ }^{45} \mathrm{Ez}$ a beolvadás s7ámszerüleg távolról sem volt olyan jelentös, mint amilyennek Opreanu elhitetni szeretné. $239-40$.

40 Berlász Jenö: Az erdélyi urbérrendezés problémái. 1770-1780. Száz. LXXV, 1941,

4t A Berlász közölte összeírás 1767-böl az egész Székelyföldön 50 román pópát ismer.

${ }^{42}$ Igy véli $\mathrm{O}$. is: i. m. 22.

${ }^{43}$ Chindea T.: Contrib. la ist. Rom. din Giurgeul Cineului. Gyergyószentmiklos, $1930,95$.

4 I. m. 56.

45 Opreanu: i. m. 21. 
Az elmondottakból kitünik, hogy a román szerző igen nehéz helyzetben volt, amikor a románok ösi voltát akarta kimutatni a Székelyföldön. Ezért szükségesnek tartotta itt-ott olyan, kissé szokatlannak minősithető módszerhez folyamodni, amely már nem áll egészen távol a hamisítás fogalmától. ${ }^{46} \mathrm{Az}$, hogy sikerült neki román körök dícsérö megemlékezését kivívnia, ${ }^{47}$ mit sem változtat érveléseinek ingatag voltán. ${ }^{4 s}$

A küzdelmet azért Opreanu még nem adta fel. A székelyföldi románság ösiségét a helynevek vizsgálatával is bizonyitani akarta. Mint a nyelvészetben teljesen járatlan, már kiindulópontja téves volt. Az 1875 után szerkeszlett osztrák-magyar kitonai térképek helynévanyagát használta fel; ez pedig nem tekinthetö teljesen megbizható anyagnak. Azonkiviul Opreanu éppen olyan területeket választott $\mathrm{ki}$ viz`gálatra, amelyekröl ö maga is jól tudja, hiszen erröl más müveiben ir, hogy részben nem rég óta lakiák románck, részben csak a múlt században csatoltattak a Székelyföldhöz. Igy sikerült neki egyik tanulmányában ${ }^{49}$ Csíkból és Gyergyóból 380 helynevet összeírni; ezekböl megállapítása szerint csak 40 magyar. Nem tekintve azt, hogy Opreanu a nyelvészetben még mükedvelönek is alig mondhaló, a fëhiba abban rejlik, hogy fiatal román helyneveket ${ }^{50}$ ösi erede'üeknek minös't. Hasonló módszert követ a vármegyei átszervezés óta megbővült Szćkelyföld déli és délnyugati részén, ahonnan mintegy 200 román nevet irt össze. ${ }^{51}$ Cpreanu müvének b’rálatában Karácsonvi János már rámutatott arra, hogy a Székelyföld legfontosabb folyónevei: Nyárád, Küküllö, Homoród, Vargyas, Feketeügy stb. magyarok, aminthogy Erdélyszerte a folyók nevei nagy többségükben magyar eredetüek. Néhányszáz újkori román dülönévnek a székely terület szélén nines bizonyítóereje

\$6 Igy pl. a románokra vonatkoztatva idezi a Szék. Okl. egy helyét (VII, 160); de ott róluk n'ég esak szó sem esik! (1. m. 27.) A lármafa szokását a Szék. Okl. I, 198. alapján román eredetünek minösiti (18.), holott az idézett helyen Mátyás király 1463_ban - a románokra utalást sem téve - egyszerüen megerösiti a véres kard köriillhordozását és a tüzhalom alkalmazását veszély esetén az erdélyi három nemzet felkelésére. A székely székeket Opreanu is román eredetüeknek ismeri (17-8).

47 Vö. Iorga ismertetését Opreanu könyvéröl: Revista Ist. 1925:132. - Magyar részrỏl ismertetést közölt a Terra Siculorumról a Magyar Kisebbség [I (1925), 73-4]. L. még: Sicu'us: A széleelypk eredetếñ. Emlékkönyv a Szék. Nemz. Múz. 50 éres jubileumára. Sepsiszentgyörgy, 1929. 643, kk.

4o L. még Upreanu útleirását a Székelyföldröl: Printre Românii săcuizați. Graiul Românese I. 1927, 8-13. Sok túlzása közül kiemelkedik, amit Udvarhelyröl mond: „neve szerint valószínüleg ez is román" (9). A csángók mind román eredetïek (11). Az elszékelvesített románok a lakosságnak täbb mint felét („mai bine de jumătate“) teszik ki (13.). Opreanu egy 1930-ban kelt írásában 60.000 igazi. 30.000 félig elszékelyesített és 200.000 teljesen elszékelyesített románról tud [Transilvania LXI (1930), 154]. Egy másik nvilatkozata szerint, ,a népnek több mint fele elidegenitett román vér, elveszett román lélek" (După 12 ani. Glas Românese (Székelyudvarhely) 1936. ápr. 10. I székelyföldi románsággal foglalkozik még egy kis füzete: $O$ anchetr̆ din.Săcuime. Cluj, 1925. (Bibl. social-econ. a rev. Soc. de mâine.)

40 Contributiuni ta toponomie din ținutul Săcuilor. Luer. Inst. de Geogr. al Univ. din Cluj. II (1924-25), 153-89.

so Vï. S-abó $T$. Attila: Gyergvói ielvnevek a XVII-XIX. századból. Bp. 1940, 5 kk. és Wachner H.: Judeţ Ciue samt Topliţa und der Mureșenge. Luer. Inst. de Geogr. al Univ. din Cluj III (1926-27), 271. (,Die national fühlenden rumänisch sprechenden Rumänen sind grösctenteile erst in neuerer Zeit eingewandert...").

51 Opreanu: Tara Săcuilor, 9. 
az elsöbbség kérdésében a régi, XVl. század elölti magyar és nem roman helynevek ezreivel szemben. ${ }^{52}$ E tények ellenére Opreanu megállapitja, hogy a Székelyföld helynévanyagából ,a román elem a legrégebbi és a legszámosabb“.53 Német részröl Liebhart Ottó a megvizsgált 460 székelyföldi helységnévböl 340 magyar $(74 \%), 90$ szláv $(19,5 \%)$ és csak 2 román $(0,5 \%)$ nevet talált: ${ }^{54}$ Albist és Szacsvát. ${ }^{55}$

A székelyföldi románok beolradásának okait keresve, Opreanu egy másik dolgozatában a föokot a rallási viszonyokban látja. „A türelmetlenségnek, az erkölcsi nyomásnak, az anyagi csábításnak kétségen kivül megvan a maga részleges, még nagyon is súlyos befolyása a jelenség elöidézésében; mégis a románok más vallásra térésének föoka a román egvházak nak e részeken való végletesen hiányos megszervezettsége."56 Opreanu igen nagyra becsüli a székelyek multbeli és mai beolvasztó erejét. Látva, hogy történelmi érrei homokos talajra épültek, éppen a vallás kérdésén keresztül, igyekszik bekapcsolni érvelésébe az emberföldrajz nyújtotta lehetöségeket, amint azt már Mihăilescu is megtette a román elem székelyföldi ösiségének bizonyítására. Opreanu az adott lehetöségekhez próbál igazodni, ezért nem a már szinte teljesen elveszett nyelvi, hanem a még tartott vallási arcvonalra helyezi a fösúlyt. ${ }^{57}$ Szerinte az emberi közösségek semmihez s£m ragasłkodnak erősehben mint vallásukhoz. Megfigveli. hogy az „oláh vallást" és a katolicizmust a Székelyföldön egyaránt a hegység védte meg a reformációtól. ${ }^{58}$ A kereszfyén hit legösibb örizöinek ezen a földën, ahol a vallások egvúttal fajokat is jelölnek, a románoknak kell lennic̈k, mert „,minél mélyebben hatolunk he a hegvek közé, annál régibb felekezeteket és népi elemeket találunk és minél inkább távolodunk a hegyektöl. annál fiatalabbak a felekeze'i rétegek és velïk a népi elemek. És mivelhogy a román egvház tapad legørorosahban a hegvhez, világos, hogv ő itt a legrégibb és vele a román elem". ${ }^{59}$ Fzt a részleteiben be nem bizonyított elgondolást megtoldja egy kis statisztikával. Sajnos elfelejti szám tásainak alapját megvilágitani. Eszerf́nt 1750 körül Udvarhelyszék lakosságának 35, 1844-ben 25 és manapság csak mintegy 3-4\%-a román vallású, a többit a magyar egyházak nyelték el. A Székelyföld többi vidé-

52 A székely helynevek és a poiitika. Magyar kisebbség II, 1927, 177-9. Vö. Bogáts Dénes: Háromszéki helynevek. Emlékkönyv a Szék. Nemz. Múz. 50 é. jub. 52-71. Módszerileg sajnos kevéssé használható. Opreanu helynéranyagát bírálja Siculusnak a 47. jegyzetben emlitett tanulmanya $(643-5)$.

53 Opreanu: Contrib. la topon. din țara Săc. 188.

54 Die Ortsnamen des Seklergebietes in. Siebenbürgen. Balkan Arehiv, III, 1927, 84. „Die krampfhaften Versuche Opreanns in seinen ,Contribuţiuni', allem, was irgendwie rumänisch klingt, kritiklos ein rum. Etymon zugrunde zu legen, werden hinfällig, sobald man die Sache genauer untersucht." Uo.

55 Ezek román voltát is elvitatja: Sipulus: i. m. 644. Szerinte Szacsva szláv, Albis az Albert becézö formája.

50 Săcuizarea Românilor prin religie. Cluj, 1927. 34 („Astra“ Bibliateca sect. Geografic etnografice. 1.).

57 „Helyesnek találtam - írja Opreanu - ezen vidék vallási kérdését is vizsgálatainknak aláretni,- még sokkal nagyobb fontosságot tulajdonítra neki, mint a lakosság mostani nyelvének." I. m. 3 .

5s I. m. $3,7-9$.

${ }^{89}$ I. m. 15. 
kein a folyamat nagyjából hasonlóan folyt volna le. ${ }^{60}$ Érdekes megfigyełd, hogy az ortodoxok rendszerint reformátusokká, a görög katolikusok pedig római katolikusokká válnak. A beolvadási folyamat 1750 körül kezdett szerinte meggyorsulni. ${ }^{61}$ Úti tapasztalataiból, egyházi jegyzőkönyvek lapjairól, feliratokról, szóbeli közlésekböl és máshonnan szerzett adatok tömegét vonultatja fel, melyeknek mindenike a románság régebbi nagyobb számát mutatja. Elhagyott templomok és temetök, elfoglalt istenházak, mindmegannyi emléke egy fényesebb román népi korszaknak. ${ }^{62}$ Mint általában a székely-román kérdésben, itt is az arányok eltúlzásában van a hiba. A román elem beolvadása a székelybe természetes folyamat volt, a felsorolt maradrányok ennek az emlékei. De fennmaradt töredékes részletekröl nagy népi tömegek múltbeli létére csak nemzeti elfogultsággal lehet következtetni. A román elem pusztulásának egyik fontos oka. ezt helyesen állapította meg Opreanu, a rosszul vagy alig megszervezett román egyházakban van. A helyzet a szerzö szerint a román uralom alatt sem változołt meg lényegesen, a beolvadás a székely elembe ma is folyik. A megoldást a két román egyház vállvetett, vetélkedés nélküli nemzeti munkájában látja, egyedül azt tekintve, hogy mindkettö elsösorban román egyház. ${ }^{63}$

A székelyföldi románság multjára ronatkozó kutatásait Opreanu 1927ben összefüggỏ nagyobb munkába összesitette. A kolozsvári román egvetem földrajzi intézele, melynek keretei közt a fiatal román földrajzkutató is müködött, szoros kapcsolatot tartott fenn a francia emberföldrajzi iskolával. Ez az iskola a földrajz személytelen természetü erőivel szemben egyoldalúan túlzolt mértékben a személyes, emberi tényezők fontosságát emelte ki. Tette pedig ezt nem emberiességből, hanem politikai érdekböl, a párizskörnyéki békék teremtette helyzet és a Franciaországgal szövetséges, németés magyarellenes utódállamok földrajzilag indokolatlan határainak rédelmére. A kolozsvári egyetem földrajzi intézete magától értetődően örömmel karolta fel ezt a szellemet, mert Románia éppen a puszta embertömeg szempontjából állt aránylag kedvezö helyzetben a többi kisantant hatalommal szemben. ${ }^{64}$ Ugyancsak természetes, hogy örömmel fogadta az országvédő, söt országhódító szellemet képviselö Opreanu törekvéseit is. Ez utóbbinak doktori értekezése, a Tinutul Săcuilor (A székelyek tartománya) ${ }^{65}$ kiszélesitése és általánositása mindannak, amit előző tanulmányaiban kifejtett, de ezen kívül még emberföldrajzi és néprajzi alapozást is adott kutatásainak. Erre már azért is szüksége volt, mert addig alkalmazott módszerei, a nemzetétől élvezett majdnem általános elismerés elle-

60 I. m. 17.

61 I. m. 34.

6: I. m. 17-3i.

63 I. m. $35-37$.

64 ,... nous eroyons que les propriétés physiques du territoire ne sont que des virtualités ou des potentiels qui acquièrent une valeur particulière au point de vue humaine, d'uhord et surtout par la capacité de création, e'est à-dire par le travail, la ténacitśs et l'intelligence des peuples." L. Someşan L.: La Transylvanie dans l'oeuvre géografique de G. Vâlsan. Revue de Transylvanie II (1935), 171-2.

65 Ținutul Săcuilor. Contribuțiuni de geografie umană şi de etnografie. Cluj, 1927, 174. (Részletes francia összefoglalással: 155-70). - Iorga ismertetését 1. Rev. ist. 1930, 112-5. 
nére sem rezettek eléggé meggyözö eredményre. Sietett tehát úja $\mathbf{W} \mathbf{W} \mathbf{E}$ léreket keresni ingatag építménye számára és ezeket a Iorga kitüzte széleskörü embertani, biológiai, néprajzi, népmüvészeti, néplélektani stb. érvekben remélte mestalálni. A székely például szerinte lélekben, jellemben, tulajdonságaiban, müvészi izlésében, vendégszeretetében, játékoshumoros hajlandóságában stb. majdnem azonos a románnal. ${ }^{66}$, ,Mindmegannyi közös tulajdonsága a székelyeknek a románokkal — írja Opreanu —, ami inkább elválasztja a székelyeket a magyaroktól, mint közelebb hozza." 67

A Tinutul Săcuilor történetileg is lényegesen túlhaladt a Terra Siculorum eredményein. Müvének első fejezetét a Székelyföld területi kialakulásának szenlelte. A román történettudomány már elötte is szivesen keresett érveket a mellett, hogy a Székelyföld nem szerres és kerek egység sem földrajzilag, sem - néprajzilag, sem történelmileg (Mihăilescu, Iorga), Opreanu különösen a népi egységröl vallott általános nézetet igyekezik lerombolni. ${ }^{68}$ A székelyek földjének népessége néprajzilag erösen kevert összetétel, amelyben a legnagyobb részt a román teszi ki. ${ }^{69}$ Politikai területe a multban kisebb volt, belsejében idegen szigetek (Felsö Fehér megye egyes részei) voltak elszórva, Moldvától elcsatolt részekkel bővült és a kiegyezés után a vármegyék megalakításakor (1876) a szomszédos megyék ¡gyes részeivel megnölt. Opreanu éppen a szélső területeket reszi a leg. tüzetesebb vizsgálat alá, ahol a székelység a szomszédos románok és szászok egy részét valóban keolvasztotta, hogy az itt tapaszlaltakat azután a belső, népileg és történelileg váltożtlan, vagy csekélyebb változásoknak ki ett részekre indokolatlanul általánosítsa. ${ }^{70} \mathrm{Az}$ ösi román elem föbb gócait a királyi rárak népében és a délháromszéki és barcasági elrománośtott szláv iełepülésekben látja. ${ }^{71}$ Szlávok és besenyök is lehettek a régi lakosság között, de kevesen és ezek hamar heolvadtak a románságba, ezért van az, hogy falvaikben késöbb románokat lalálunk. Végkövetkeztetése az, hogy ,már eleitől fogva az úgyneiezeft Székelyföld nem volt egészen a székelveké"72 és ,a népesség nagvját mind a korona birtokain, mind a tartomány belsejében . . . kétségtelenül románok képezték."73

A Tinutul Săcuilor legnagyobb részét sok utánjárással készült emberföldrajzi és néprajzi fejtegetések foglalják el. A magvar szakembereknek kötelességük volna az ott felvetett rengeteg kérdésre megfeleló tudományos választ adni. Ami a kérdés tc̈rténelmi részét illeti, szintén nagy szükség volna, függetlenül minden vitától, a legkorszerübb módøzerek alkalmazásával, elkész'teni az egész Székelyföłd település- és népiségtờrténetét. Opreanunak és a többi román kutatónak megállapításai nem maradtak

6. I. M. $162-3$

a? I. m. 69.

68 I. m. 19.

68 I. m. 66.

70 ,Ami a széleken történt... ugyanúgy kellett történnie a Székelyföld egészébsn régeblen." I. h. 19.

71 I. m. 13-5.

72 I. m. 14.

73 I. m. $18-9$. 
ismeretlenek a külfüld clött sem. A Tinutul Săctilor francia kironaEMME újabban Opreanu összes eredményeinek összefoglalása egy német nyelven megjelent kötetben ${ }^{74}$ új feladatokra hívják a magyar kutatókat. A kedvezö bírálat, amellyel német részröl ezt a müvet fogadták ${ }^{75}$ bizonyitja, hogy a székely-román kérdésben a magyar tudományosság már nem sokáig hallgathat, ha azt akarja, hogy álláspontja érvényesüljön.

Amit Opreanu az egész Székelyfölddel, részletesebben Udvarhely megyével kapcsolatban elvégzett, azt kíséreli meg szerényebb felkészültséggel Gyergyóról szóló könyvében egy gyergyószentmiklósi tanár, Chindea Tódor. ${ }^{76} O$ is fájdalommal figyeli, hogy , az itteni székely falvakban egyetlen román sem beszéli és ismeri ösei nyelvét“. iT Fökérdése a gyergyói románság ösiségének és folytonosságának bizonyítása. Ámbár erre semmi támpontja ninesen, a románokat tartja Gyergyó lakosainak a székelyek megjelenésekor, amit a tatárjárás utánra helyez. A szláv nelyneveket a szokott módon románoknak minösíti, mert a székelyek bevándorlásakor az ottani szlávság már egészen beleolvadt a románságba. ${ }^{i 8}$ A székelyè közt található román nevek a beolvadt románok késői emlékei. Román kölcsönszók tömegéröl beszél, de csak négyet sorol fel (ájer, esztena, sztrunga, csobán). ${ }^{79}$ Amint látjuk, Chindea szerint a románság a szlávokkal szemben megörizte beolvasztó erejét, a székelyek hatása ilyen szempontból már régzetes volt. Ennek okát nem keresi és nem nyilatkozik a beolvasztott románok arányszámáról sem. A gyergyói románság történetében a XVI. században a számbeli erösödés korszaka kezdödik, párhuzamosan a székely jogok aláhanyattásával, a birtokos nemesek, elsösorban a Lázárok fobbágytelepítései révén. Ekkor telepednek be Moldovából egy Lázár birtokra a mai egyetlen tiszta román lakosságú gyergyai falu, Vasláb lakosai. ${ }^{\text {9. }}$ Közben az elszékelyesedés folyamata nem szünik meg, söt fokozódik. A berándorló ortodox románok egy része már Lipót, naģobb tömege Mária Terézia alatt görög katolikussá lett. A felekezetváltoztatás lényegesen megkönnyítelte a nemzetiségi beolvadást is. ${ }^{81}$ Chindea egyebekben Iorga és Opreanu nyomdokain halad. ${ }^{92}$ Mint gimnáziumi igazgató és a gyergyószentmiklósi román hetilapnak, a Gazeta Ciucului-nak egy ideig szerkesztöje, Chindea lelkes munkát folytatott. Lapjában egy sereg tanulmányt és apróbb

74 Die Szekler. Eine völkische Minderheit inmitten des Rumänentums. Sibiu, 1939. 211 1. + 9 térkép + 3 tábla.

75 Vö. Malaschofsky A. ismertetését: Südostforschungen VI (1940), 698-701. Itt olvassuk: "Schon allein dadurch, dass er in deutscher Sprache geschrieben ist, vor vielen madjarischen Darstellungen im Vorteil ist", (701. 1.).

76 Contribuția la istoria Românilor din Giurgeul Ciucului. Gyergyószentmiklós, 1930. 150. 1. - A székely-román müveket állandó figyelemmel kísérö Iorga ismertetését 1.:

Rev. Ist. $1930,163$.

77 I. m. 25.

73 I. m. $21-3,27,29$.

79 I. m. $30-9,22$.

80 I. m. $56-65,79$.

81 I. m. 97.

s2 Chindea egy másik csíki vonatkozású müve, amellyel a helyi románság történelmi tudatát próbálta nevelni: Monumente istorice în Ciue. Gyergyószentmiklós. 1933. 58 1. Iorgs ism.: Rev. Ist. 1933, 374. 


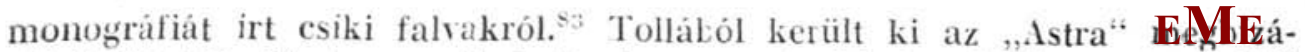
sából írt két füzete a szèkelyeknek a románokkal való kapcsolatairól. ${ }^{84}$ Ezeket a székely nép körében terjesztettẻk.

Opreanu és Chindea után nehány esztendövel Popa-Lisseanu György tanár, neves tudós, a román kamara volt elnöke szállt a küzdötérre. 1932 december 1-én az "Astra" rendezésében Székelykereszturon tartott elöadást a székelyek románságáról. Az elöadás anyagát, mint egy késöbb meg.jelenendö nagyobb mü elöhírnökét, könyvecske formájában hozla nyilvánosságra. ${ }^{85}$ Tervezett nagyobb munkájában közölni akarta az összes ,„egészen vagy részben román eredetü" székelyek teljes névsorát. Iorga és Opreanu után alig hoz új történelmi érveket a székelyek részleges román eredete mellelt. Inkább a székelyek eredetére vonatkozó magyar irodalom sokszor teljesen elavult nézeteit próbálja román érdekeknek megfelelöen elöadni.

A románok ,elszékelyesitését ${ }^{\text {" }}$ Popa-Lisseanu a magyar eröszaknak tulajdonitja. Felhasználva az eröltetett okoskodás százféle módjät, részletes tárgyalás alá reszi ezt az ,eröszakot". A mesterséges elnemzetietlenités eszközei a vallás, az iskola, a hadsereg, a közigazgatás lettek volna. ${ }^{86} \mathrm{~A}$ székelyek román eredetének bizonyitékait bizonyos szokások, énekek, helyés személynevek stb. románságában keresi. ${ }^{87}$ A románok kétszáz érvel ezelötti arányszámát a Székelyföldön $30 \%$-ra becsüli. ${ }^{88} \mathrm{Az}$ elszékelyesedés jelensége mélységes csodálkozást vált ki belöle, mert tudomása szerint a románság és a magyarság együttélése rendesen az utóbbira nézve szokott ,,végzetessé“ rálni. Itt nem ez történt, „holott természelesebb lett volna, ha honfitársaink (a székelyek) románosodtak volna el."80 „Valahányszor valeki közüiünk székely vidékre megy - írja — és mindenütt csak Ârpád nyelvét hallja beszélni, kisértésbe esik azt hinni, hogy tiszta magyar vidék kellös közepén van és næm is veszi észre, hogy saját testrérei közt van, akik teljesen elvesztették az ősi nyelvet és hitet."90 Ilyen öncsalással járkel Popa-Lisseanu a székelyek közt abhan a hiszemben, hogy sikerül majd bennük a román nemzeti érzést felébreszteni. Barátságos bánásmóddal gondolja visszatéríthetni a székelyt ,,román ősei“ kebelére. Ilyen téveszméktöl hemzsegő müvét dr. Kendy Sándor igen sikertelen magyar fordításában ${ }^{91}$ ingyen terjeszti a székelyföldi lakosság körében, természetesen a románnyelvü kiadással szemben ralamelyes változtatásokkal. Csinos kül-

s3 A Gazeta Ciucului-ban: Tölgyes (1934. febr. 1, 15.); Mikfalva (márc. 1.); Vasláb (ápr. 15, máj. 15, jún. 1.); Botineani (jún. 15.); Békás (júl., szept. 1, 15, okt. 1.); Gyergyóvárhely-Várvíz (okt. 15. nov. 1, 15.); Ditróhodos (1935. jan. 1.). Iorga felfigyelt ezekre a dolgozatokra és kötetben akarta őket kiadni (Vö. Gaz. Ciuc. 1934. júl. 1.) Nines tudomásom róla, hogy ez a kötet ralóban meg is jelent volna.

84 A székelyek és ezeknek összeköttetése a román fejedelemségekkel 1526 ig. Sibiu 1938, 64 1.; A székelyek viszonya a román fejedelemségekkel 1527-től napjainkig. Sibiu, 1938. 95. 1. A történelmi valóságot gyökeresen mellözö tartalmukkal más vonatkozásban fogok foglalkozni.

85 Secui şi secuižarea Românilor. Buc., 1932. 621.

se I. m. $39-54$.

s7 I. m. $54-59$.

88 I. m. 38 .

so I. m. 7 .

- Date privitoare la maghiarizarea Românilor. Buc. 1937, 31.

o1 A székelyek és a románok székelyesítése. Buk., 1936. 1261. 
söben megjelent francia fordítása ${ }^{92}$ a külföldet volt hivatva tájékoztatni a székely kérdést illető román állásfoglalásról. Nem szorul bövebb magyarázatra, hogy Popa-Lisseanu terékenységét nem lehet pusztán egyéni kezdeményezésnek tekinteni. Csak természetes az is, hogy mindkét fordításból - igen bölcsen - kimaradtak a ,visszarománositás“-ról irott eszmefuttatásai, mint pl. a következö: „Székely honfilársainkkal szemben járjunk el türelemmel és jóindulattal. Beszéljünk nekik csendesen a multról, és mutassuk be nekik, hogy a néptani és embertani tudomány adatai szerint is alig van valami különbség köztük és köztünk. A székely rövidfejüség például az ugyanazon vidékröl való románjaink rövidfejüsége, s a székely vér vizsgálata, különbözőleg a pusztai magyar vértöl, ugyanazt a jelzöszámot mutatja, mint a román vér. A székelyek iránt, akikkel a románok multjukban mindíg jó viszonyban éltek, adjuk barátságunk tanujelét, mert ök nagyrészben, azt merném mondani legnagyobb többségükben a mi testréreink, elveszelt testréreink, de mégis testvéreink, akikikel szemben illik testvéri érzelmeket táplálnunk. Akik közülük önként vissza akarnának jönni anyjuk kebelére, lássuk szívesen; akik mai helyzetükben fognak kitartani, azokat tekintsük magyar nyelvü és vallású vérrokonainknak. De mindenféle úlon-módon igyekezzünk bebizonyitani nekik népi eredetüket és adjuk meg nekik ennek az eredetnek öntudatát."03

Szükségtelen rámutatni, hogy a fentihez hasonló tanulmảnynak semmi köze sincs a tudományhoz, ${ }^{94}$ ellenben igen sok köze van a gyakorlati politikához, amint ezt a legutóbbi idézet meggyözően bizonyitja. PopaLisseanu beharengozott nagy müve ${ }^{95}$ sem lett tudomány, csak egyszerü újság'rás és belföldi hírverés. Apróbb közlemények formájában először a bukaresti „Universul“ hasábjain jelent meg sorozatosan, ahonnan vidéki napilapok és folyóiratok is gyakran átvették és közismertté tették. PopaLisseanu cikkeit az Antireviziós-Liga rendelkezésére bocsảtotta s ez kötetben ki is adla. Nár ez is mutatja a mü rendeltetését. A szokott slílusban, magas hanghordozással, de ugyanazon ingatag érveléssel, nemcsak a székelység, hanem az egész magyar faj és a magyar nemzeti állam létezését és létjogosultságát is kétségbevonja. ${ }^{96}$ Erre a lebecsülésre és a székelység magyarságának kétségbevonására már a Romániára kénvszeríte't kisebbségi szerződés 11. pontjában kilátásba helyezett székely önkormányzat elhárítása miatt is szükség volt. Míg a magyarországi irredenta-mozgalom nemzetkëzi riszonylathan nem volt jelentös tényezö, elöfordulhatott mint azt Lăpědatu esetében láttuk, - hogy még vezető szerepet játszó román politikusok közt sem idegenkedtek fellétlenül a székelyek önkormányzatától. Az Universultól 1932-ben szenvedélyes erővel felszabad'tott antirevizionista hadjárat korában azonban az ilyesmi több volt mint kor-

๑2 Sicules et Roumains. Un proces de dénationalisation. Buc., 1933! 1-80 1. - 2. kiad. Buc., 1939.

93 A székelyek és a románok székelyesítése. 61.

94 Izelítöül. Popa Lisseanu gyermeteg nyelvészkedésére emlitsük meg, hogy a vár szót szlávnak tartja; a "mongol népek" nem tudván kiejteni a szókezdỏ v-t, a város szó (románul oraş) a múltban magyarul bizonyára áros nak hangzott (१). Secuii și sec. R. 25.

95 Date privitoare la maghiarizarea Românilor. Buc., 1937. 931.

90 Vö. Graiul românesc: Limba româneasea în vicleimul secuesc. VII (1933), 2731. - Un proces de desnaţionalizare. Uo. VII (1933), 100-3. stb. 
szerütlenség. A székelységben, helyesebben a székelyföldi magyar értelmiségi rétegben a románok általában a magyar revizionizmus elöretolt állását látlák. Az ú. n. visszarománosító mozgalom nagy fellendülésének a magyarázata ebben az idöben a román társadalom nagy félelme a székely önkormányzattól és az azon túl látott magyar irredentizmustól. ${ }^{97}$

$\mathrm{Az}$ ismertebb nerü erdélyi román földrajzkulatók közül Someșan Laurian foglalkozik a székely-román kérdéssel egy földrajzi és történelmi feltevésekkel teletömött rövid tanulmányában. ${ }^{98} \mathrm{~A}$ román népi elemtöl képezett ovális idom a földrajzi erök legtermészetesebb alkotása, ezért a románság közepén található székelység természetellenes jelenség. A székelyek Bihartól kezdve a Keleti Kárpátokig fokról-fokra terjeszkedtek és ez a folyamat csak a XIX. (!) században fejezödölt be. Opreanu érveire feltétel nélkül esküszik. Gyakorlatilag sürgeti az elszékelyesítés (nem: elszékelyesedés) megállítását és az elveszelt román elem gyors visszahóditását.

Meteş István, egyik jónerü román történész egyszerüen tagadóba veszi a székelyek magyar jellegét. ${ }^{99}$ A magyarok minden erőfeszitése, hogy egyesítsék a két népet, különösen az elmúlt évszázad óta, meddö maradt. Véleménye szerint a székelyek magyarul csak a XIV. században tanultak meg. Hibáztatja a román kormányt, amiért még az 1930-i népszámlálásában is egy népnek reszi a magyart és a székelyt.

Közismert Lupaş János egyetemi tanár álláspontja a székely széki intézmény eredelét illetöleg. ${ }^{100}$ Természetesen a románok elsőbbségét vallja a Székelyföldön, ahol a beköltözködö székelyek csak a XIV. században népesítik be Háromszéket. A székely és a szász székek a jus valachicumból kerültek volna át a jövevények társadalmi és politikai berendezkedésébe.

3.

Ủj szempontokat szállít a román álláspont támogatására Sulica Miklós volt marosvásárhelyi középiskolai tanár.101 Ö sem tudott megszabadulni a divatos székely-román tan elöitéletes szemléletétöl. A székelyföldi román folytonosság érinthetetlen dogma elötte is. Még a székely-magyar népi azonosságot sem ismeri el, söt odáig megy, hogy a székely törlénetet nem a magyar, hanem a román nemzeti történet részének nyilvánítja. „A székelyek mindennapi élete egybefonódott és összetévesztödött a közöttük élỏ

97 „... a magyar állam sohasem volt nemzeti állam, mely szervesen, saját belsö erejéböl "fejlödött volna ki, mint a magyar fajta kifejezése, hanem összetett, több nemzetböl áll6, a római egyház hatalmát képviselö $\epsilon$ s idegen: német, olasz, szláv, román stb. elemekre támaszkodó állam..." Ezek az idegen elemek alkották szerinte minden idöben a magyarok szellemi rétegeit. Date priv. 6-7.

98 Vö. i. m. 31.

99 O problemă etnică în estul Transilvaniei. Reînvierea (Marosvásárhely), 1938. jan.máre. $8-10$.

100 Secuii nu sunt Unguri. Datoria Statului român faf̧a de Secui. România Eroică. 1937. máj. 1. és Glas românesc în fara secuizată. 1937. jún. 17.

101 Réalités historiques dan le voivodat de Transylvanie du XII_e au XVI-e siècle. (L.: La Transylvanie. Buc. 1938.). - Lupaş sem vesz tudomást az 1301.i oláhfalvi oklerél hamisítvány voltáról. A Barcaságon a német lovagrendet és a székelyeket megelö. zően román politikai alakulat (Terra Blachorum) létezett volna (197-8, 208-9 l.). 
román tömegekkel, amelyeket lassacskán beolvasztottak és minden nagy katonai és politikai ténykedésükben érdekközösséget vállaltak a két román fejedelemségbeli nagy vajdáinkkal. Szervesen beleilleszkedve népünk történetébe és nem a magyar történelbe, a székelyek multja nem a magyar történelemnek, hanem — elsö sorban — a román történelemnek egy külön fejezete".102 A magyar elnyomás átalakithatta a székelyföldi románokat, azért mégis minden lényeges testi és lelki vonásukban románok, s mégha magyarul is beszélnek, ,román fajtánk testéböl való test, lelkéböl való lélek" maradtak. Ebböl a felfogásból következik a visszahódítás lehetösége, söt kötelessége, amit Sulica Opreanunál és Popa-Lisseanunál nem kisebb hévvel hirdet. ${ }^{103}$ Sulica beállítása szerint a szigorú ferencrendi szerzetesek (observánsok) megjelenése a XV. század negy:enes éveiben a Székelyföldön, közelebbröl Marosvásárhelyt és Csíksomlyón a római katolicizmus térítői szándékából származik az orthodoxiát képviselö székelyföldi románok iránt. Ha Moldva és Havaselve eretnekei vagy pogány kúnjai és tatárai ellen irányult volna az intézkedés, :kkor elsösorban ott és nem a Székelyföldön lelepedtek volna le. ${ }^{104}$ IV. Jenó pápa egyik oklerelére ${ }^{105}$ hivatkozik (1444. febr. 1.); ebben ez a ferencrendiek müködéséról és a helybeli lakosok hódításairól emlékezik meg a katolicizmus rovására. Az oklevél azt is elárulja, hogy az illelö vidéken nincsenek huszilák. Kik ellen irányul tehít a ferenc. rendi propaganda? - kérdi Sulica. - Az ortodox románok ellen!106

Sulica az oklevelet nagyon felületesen olvashatta el, mert tartalmát többszërösen félremagyarázza. Az idézett oklevélhen IV. Jenö pápa a salvatoriánus (vagy observáns) ferencrendiek boszniai vikáriátusa alá rendeli és vele egyesiti a rendnek Scythiában (Havaselvén), Moldvában és a Székelyföldön lakó konventjeit, háżit, név szerint a székelyvásárhelvit. (Marosıásárhely régebbi neve.) Ezek a szerzelesek nem a székelyföldi feltételezett románok elleni hódilóhadjáratra készïltek, hiszen az oklevél világosan kifejezi rendeltetésüket: Scythiảban, ahol sok a pogány, Krisztus egyházát tartoznak lerjeszteni; ${ }^{10}$. Moldvában a szakadár orthodoxok és az eretnek husziták ellen kell küzdeniök.108 A Székelyföldön nem a huszitákkal kell hadakozniok, mert olt ilyenek nincsenek, mondja az oklevél, hanem segíteniök ke!l az ottani nyomaszló paphiányon. ${ }^{109} \mathrm{Ha}$ itt is a schismatikusokkal kellett volna meghirkózniok, akkor ezt a pápa el nem mulasz-

102 Contribuții la istoria vechimei elementului românesc şi a cireulației cărţii românești în regiumle săcuizate. Reînvierea (Marosvásárhely), 1937. nov. 11-22; 1938. jan.máre. 11-29.

${ }^{103}$ I. m. 1937. nor. $11-2$.

104 I. m. 18.

105 I. m. 12. S. nem tud róla, hogy a ferenceseknek volt kolostoruk Bákóban, söt Hunyadi János Kiliában is letelepitette öket (1448). L. Karácsonyi Janos: Szent Ferenc rendjének története Magyarországon. Bp. 1923, I, 347. és 341.

106 Szék. Okl. I, 147-53.

107 I. m. 13.

$108, \ldots$ in Scythie partibus in quibus paganorum multitudo consistit..." 147 .

$108, \ldots$ et in Moldavie, in quibus tam a longis pestiferum virus sehismatis, quod adhuc nonnullos illarum partium populos, qui ad Romane Ecclesie vnitatem nuper redierunt, inficere non desinit, quam a paucis temporibus atra prawitate heretice et potissimum Hussitarum dethifera pestis in maximum Christianae fidei detrimentum, quamplurima geraninarunt peruersa germina..." (147. k). 
totta volna lelkükre kötni. Egyébként a pápa lényegében ugyanezeket irta évekkel azelötl Benedek szörényi püspöknek is. ${ }^{110}$ Nincs tehát semmi alapja Sulica feltételezésének, mely szerint a ferencesek a Székelyföldön az ortodoxok megtérítésén fáradoztak rolna. Még indokolatlanabb merész küret. keztetése: „Ezeknek a ferenceseknek a terékenykedése a Székelyfö!dön kétségbevonhatatlanul igazolja a román népesség számbeli fölényét (!) a középkorban a négy székely megyében".111

Új érve az is, hogy a régi székely templomok falfestészeteben román egyházi hatást vél felfedezni; igy román (oláh) müvészi hatást a maross7entannai és a marosszentkirályi templomok XIV. századbeli freskóin. A maross7entkirályi lemplom falán még 1870-ben látható volt agy freskórészlet, pazar ,román“ ruhábạ öltözött leányalakkal. ${ }^{112} \mathrm{~A}$ marosvásárhelyi mai református vártemplom melletti bástyaszerü épület belső falán még félszázaddal ezelött látható volt egy bizánci stílusú festmény. Az alap'tót ábrázolta, kezében a templom kicsinyitett másával. $\mathrm{Ez}$ az ábrázolási mód szerinte „kiváltképen román szokás“; ezt a ferencesek csakis a román egyháznüveszethöl vehették át ${ }^{112}$

Sulica fenti értesüléseit lielymegjelölés nélkül közli, de nyilvánvalóan Orbán Balázstól vette öket, elég szabad értelmezéssel és saját köretkeztetéseivel megtoldva. Sulica nem beszél részletesebben a szentannai templomról, mert erröl Orbán Baláz nak sines sok szava. A falu már az 1332-i pápai dézsmajegyzékben szerepelt, tehát akkor lakosai katolikus magyarok voltak. 1497-böl való nyolc mázsás harangja mutatja, hogy lakossága a XV. század végén is katolikus volt. Ma Szentanna regyes lakosságú, de tudjuk, hogv mikor kerültek beléje románok. Az 1614-i lustrában a lakosok még mind székelyek, de utána hamarosan Balázsi Mihály románokat telepí a faluba ${ }^{114}$ Az ortodox festömüvészetnek bajosan lehetett alkalma megihletni a szentannai freskók müvészét. mert román lakosság jelenléte nincs bebizonvítva és mert orthodox jellegü festészeti alkotás sincs a középkorban a Székelyföldën. Ug̣anıkkor a katolikus egyházi festészetre számos példánk van ugvanezen a területen. këzelehbrël épen a szóhan forgó szentkirálvi temblomban is. Ez is a XIII. században épült román ízlésü épület, akárcsak a szentannai, hívei ugyanúgy magyarok lehettek, nyomukról a fentemlített pápai tizedjegyzék is tanúskodik. A község elnevezése maga is Szent István királyra utal. A hajó és a szentély belsö falait díszítö freskókról Orbán Balázs csak annyit ír, hogy ,,élénk színei a hulladozó vakolat alól itt-ott

150 „.... in quibus licet heretice prawitatis pestis huiusmodi notorie non apparet, propter tamen eclesiasticaum personarum cure animorum intendere debentium paucitatem, nee non Diecesium nimiam distantiam ab eisdem populis, quasi doctrine fideique, (cum ibidem pauci admodum vel quasi nulli sint, qui illis verbum Dominicorum annuncient), in dies magis redduntur ignari...', (148. 1.).

111 1439: ,....non solum ipsa terra Moldavie, in qua Graecana heresis quoque quotidie magis are magis pululare dicitur, sed in finitimi terre Ciculi, partesque Transalpine, deficientibus ijsdem in oris eciam fratribus ordinis minorum, ecelesiasticarum personarum inopia vel maxime perisuloso hơ tempore laborent..." (Szék. Okl. I, 143.).

112 Sulica: I. m. 13.

113 Uo.

114 I. m. 14. - Ugyłanezt a tételt részletesebben kifejti Sulica Relațile lui Mihai Viteazul en oraşul Târgu Mureş címü tanulmányában. Târgu-Mureș, 1929, 11-5. 
most is kitetszenek" "115 Sulica nem árulja el, hogy további részletezését a falképek tartalmáról (román ruhás fiatal leányról ír), honnan veszi. Benkő Károly görög szentek képeit emlegeti ${ }^{116}$ a szentkirályi templom falfestményeivel kapcsolatban, de cs:ı hallomásból łud róluk. ${ }^{116}$ Valószinüleg Benkö megjegyzése sugallta Sulica ötletét az ortodox müvészi hatásról. A szentkirályi és a szentannai freskókat 1894-ben és 1897-ben Kelemen Lajos és Nemes Ödön tárta fel, az utóbbi rajzokat is készítelt róluk. Ezek az Erdélyi Múzeum levéltárában máig megvannak. A festményeken Szent István és Erdély védője, Szent László is szerepel. ${ }^{117}$ Semmi sem jogosítja fel tehát Sulicát, hogy az említett falfestményeken ortodox román hatást feltételezzen és hogy ezen túl a marosszéki románság számbeli erejére következtessen.

Amit Sulica a marosvásárhelyi templom melletti épület belsejében levö festményröl mond, annak forrása szintén Orbán Balázs lehetett; ö ugyanis a templom tartozékáról, az iskolaházról Nemes Gábor 1790 körüli feljegyzései alapján említi meg, hogy az épületet Mihály vajda oratoriumának tartják és belsejében görög szentek képei láthatók. Orbán Balázs kijavitja Nemes értesülését, megjegyezve, hogy azt az épületet Mihály vajda nem épittethette, mert sokkal régebbi korból származik. A festmények már akkor rendkívül rongált maradványait le is írta. „A csak körvonalaiban látszó alakok egyike térdelve fohászkodó magyar öltönyü férfi, ki kezében a m.-vásárhelyi templomkastély mintáját mutatja fel a felhökbe lebegö szent szüznek, s következöleg egy votiv kép..." Orbán Balázs Báthory István vajdára, vagy valamelyik még korábbi föúrra gondol. A többi alakok teljesen megsemmisüiltek, körvonalaikból még ruhájukat sem lehet kivenni és a festmény keletkezési idejére következtetni. ${ }^{118}$ Sulica állitása, mely szerint az alapító ábrázolása a tỏle felajánlott épület kicsinyített másával kifejezetten román szokás volna, annyira téves, hogy cáfolatára felesleges kitérni. Az. eddigiekből kitetszik, hogy Sulica Orbán adatait célzatos kihagyással, másutt megtoldással és a forrás meg nem jelölésével használta, s ezáltal a valóságot inkább megkerülte, mintsem kereste. Végeredményben az ortodox egyházi müvészet hatásáról való érvelése gyökeresen téves és alaptalan.

Sulica szerint még a XVI. században is a székelyek és a románok egyazon területen egybeolvadás nélkül éltek, ,de a közös életkörülménvek és a közös érdekek arra kényszerítették (a románokat), hogy tekintsék magukat egynek (a székelyekkel) és társuljanak ezek tetleihez, hogv ígv ugyanazon politikai egység színe alatt jelenjenek meg és hogy összefoglaló 'székely' név alatt mutatkozzanak." Nem hiányzott a „román öszlön“ sem, „,mely még eröteljesen ott rezgett a részhen elnemzetietlenítelt, részben : székelyek közé szétszórt román tömegekben, anélkül, hogv elvesztették volna nyelvüket és külön román létük tudatát".119 Ezt a különleges székelyföldi népi helyzetet használta volna ki Mihály vajda, akit ezek szerint a székely

115 Orbân Balázs: A Székelyföld leírása. Pest, 1870. IV, 188-9. - Benkö Károly: Marosszék ismertetêse. Kolozsvár, 1868-9. 346.

110 ,... . bemeszelt falain - azt anlítjúk, kik látták, hogy - görög szentek képei íratokkal környezve volnának" (I. m. 329.).

117 Orbain: i. m. IV, 183.

118 Kelemen Lajos múzeumi és levéltári föigazgató úr szíves közlése.

119 Orban: i. m. IV, 128. 


\section{$\mathbf{E M} \mathbf{E}^{23}$}

név alatt rejtözö románok segítettek volna harcaiban. És minthogy Mihály a székelyek jogait visszaadó oklevélben ezt a kifejezést használja: „Siculi et incolce sedium siculicalium", (amely ,lakosok"-on a székely jogokkal nem rendelkezö jobbágy és földönlakó elemet kell érteni), Sulica ezekben a nemszékelyekben azonnal románokat fedez fel és elhamarkodottan így itélkezik: „Mihály vajda kifejezése minden kétségen felül igazolja 1600-ban a románoknak, mint külön és számos, a székelyektöl be nem olvasztott népi elemnek székelyföldi létezését" ${ }^{120}$

Ha a székelyföldi románság 1600 körül ilyen virágzó lett volna, akkor hogyan magyarázható későbbi gyors hanyatlása? Sulica a puszlulás okát minden más ok felett a vallási unióban keresi. Az unió Erdélyszerte megbontotta a románság egységét, de népiségi változást csak ott tudott elöidézni, ahol a románság szétszórlan élt, mint például a Székelyföldön. Itt a veszteség egyenesen végzetes volt. Csak a székely vidékek szélein, ahol nagyobb román tëmegekkel érintkezik, maradt meg többé-kevésbbé eredeti miroltában a román. A XIX. század elsö felére a folyamat majdnem elérte beteljesedését. ${ }^{121}$

Miután kisérletet telt arra, hogy a székelyföldi románság tekintélyes szellemi értékeit bizonvitsa be a katolikus egvházi festészelre tett hatásával, most az elmult századok román єgyházi könyvforgalmából próbál tőkét kovácsolni. Cs'kban és Maros-Tordában találtak két 1512-ből származó târgoviş'ei cgyházi könyvet (szláv evangelium). Fbböl az egvetemes románság XVI. századeleji szellemi egységét olvassa ki és a szellemi műveltség messzenyuló hagyományát csillogłatja meg a székelyföldi románok körében. ${ }^{22}$ Hogy közelebbröl hol és milyen körülmények közt találták meg a nevezett két könyvet, arról nem nyilatkozott. Megjegyzendő, hogy egy valószínüleg 1565-böl származó kálvinista Coresi nyomlatványon kívül (Cazania şi Molitvelnic) 1683-ig nem ismeretes a Székelyföldröl származó egyetlen román egyházi könyv sem. ${ }^{123}$

Röriden: Sulica a románság régiségét új érvekkel próbálta bebizonvitani az eredetileg románnak elképzelt Székelvföldön. Ítélelének tárgyilago;ságáhan lépten-nyomon megঃkadályozta túlzott nemzeti buzgalma és el nem hallgatctt vágya az ,elszékelyesilettek visszarománosítására“. A románság pusztulását az egyház elgyengülésében látja, ennek oka pedig a vallá:i unió. U'gvanakkor az egyházran keresi a román nemzetiség megmaradácán̊k tiłkát és az eselleges ,.visszarománosítás" sikerét is. Semmilven más intézménynek nem jut hozzá hasonló feladat a visszarománosítási hadiárathan. mert a román nemzetiség központi lénvegét az egyház hordozza úgyannyira, hogy a nyelv elvesztése nem ér fel az ortodox, vagy a vele szertartásban azonos görög katolikus egyházból való kilépés veszedelmével. ${ }^{124}$

\footnotetext{
120 Contribuții, 15.

121. I. m. 17 .

122 I. m. 1938. jan,-máre, 18-24.

123 I. m. 19-20.

124 Vö. i. m. 21.
} 
Mielött befejezném beszámolómat a román történettudományos tönekvésekröl a székelyföldi románság szélesebb sodrú elmúlt életének bizonyítására, vissza kell térnünk ahhoz a Iorgához, aki a székely-román kérdés szellemi elindítója volt. Egy 1938-ban elhangzott rádióbieszédében visszatért a székely-román kérdésre és újszerü magyarázatot próbált adni a székelyek sokat emlegetett eredetkérdésére. Maga Iorga eddig egyeredetünek vette a székelyeket a magyarokkal. ${ }^{25}$ Most szembefordult ezzel a nézetével, mert nem találta valószínünek, hogy a magyar királyok olyan messze, a magyarság törzsétöl teljesen elszakítva küldték volna a székelyeket határt örizni Erdély keletére. Az Erdélyben letelepitett szászok nem vollak határörök, azért volt szükség a katonai szervezetü német lovagrend behozatalára. Csakhogy ezek is kevesen voltak és ezért a lovagok mint katonai elemre, a már ott élö lakosokra szorultak. Ezek pedig nem voltak mások mint a - székelyek! A német lovagok - és nem a magyar királyok - telepítették le őket falvakba, ezért riselnek ezek a telepítések oly gvakran katolikus szentneveket. A rend kitakarodása után ottmaradt alattvalók továbbra is megtartotlák katonai elöjogaikat és ezentúl külön szervezetben a magyar koronával kerültek függö viszonyba. A német lovagoknak köszönhették katolikus rallásukat is. ${ }^{126}$

De kik voltak ezek a rejtelmes székelyek és honnan kerïltek ide? Iorga határozoltan állitja, hogy nem voltak magyarok és hogy nem nyugatról kerültek a Keleti Kárpátok vidékére. Fgy ..más barhár elemröl“ van itt szó, s ez a székelyek és a csángók közös őse. Iorga összekapcsolja a székely és a csángó kérdést és a kettöt együtt próbálja megérteni. A Kárpátok gerince (șiră de spinare) azoknak a finn-turáni településeknek, amelyek a Küküllöktöl ${ }^{127}$ elszórtan a Dnyeszterig (Ciubărciu) tartanak. ${ }^{128}$ A székelycsángó-elöd török nép nem egymagában vette birtokába a töle lakott területet, hanem az őstörténelem óta lakott helyeken élö románsággal került a legszorosabb barátságos kapcsolatba. Az új területen a barátságos együttélés vérkeveredésre vezetett a románokkal, részhen a szászokkal is. Ezért a székelyek egyes részeken balti-finn tipusúak, másult a szászokhoz hasonlítanak, régül ,,az ott lakók nagyrẹ́sze a román nép összes vonásaival rendelkezik és ez megmulalja igazi eredetüket... Következésképen egy fajkeverékkel van dolgunk, amelyböl az elsödleges elem egyáltalában nem hasonlít a magyarok általános típusához."129 „Világos - fejtegeti tovább Iorga -, hogv a székelyek, valamint a szászok is nem tettek egyebet, minthogv kölesön vették annak a román nėpességnek patriarkálissá vált ősi római s7ervezeti formáit, amely nem mindenütt élt rajdák alalt és nem kerïI! alattvalói helyzetbe bizonyos szélesebb értelemben vett uralkodókkal." 130

125 I. m. 29.

120 Consideratii noi asupra rostului Secuilor. Conferinţă la radio (1938). Bue., 1939.

Klny. a Rev. Ist.-b61.

127 I. m. 4-6.

128 Ezek török neve szerinte a székelyektől származna (I. m. 9.).

129 I. m. 8-9.

130 I. m. 6. 
Itt a ,Romaniák' -ról szóló régi, kedvenc gondolatát terjesztette ki a Székelyföldre. Romániáknak nevezte el Iorga a felbomlott római birodalomnak azokat a félig megszervezett latin nyelven beszélö lakosságú politikai egységeit, amelyekkel gyakran a felülkerekedö barbárok is azonosílották magukat. A „Romaniae“ mintegy a latinság önálló formái voltak a birodalmon kívïl. ${ }^{131}$ Iorga ezeknek az egységeknek azt a hivatást szánta, hogv a római birodalom és a késöbbi politikai alakulatok, de elsö sorban a késöbbi román Románia közt szerves kapcsolatot létesítsenek. ${ }^{132}$ Romániákat tételez fel Skóciától kezdve le Délitáliáig és Svájctól Délbesszará biáig. ${ }^{133} \mathrm{Az}$ eddigi Romániák sorát Iorga most egy székely Romániával toldja meg. Az öslakó románok a székelyek öseit képviselö törökfajú népnek átadták a középkor egy bizonyos korában jellegzetes népi politikai formát. „Tehát van egy székely Románia-féle is, amit a római Romániák, köztük a mienk és bizonyos germán Romániák mellé helyzehetünk ..."134 Ismeretes Iorga törekvése a Dáciában megmaradottnak feltételezett románok és a különféle barbár népek: húnok, avarok, később besenyők és kúnok közt a barátságos együttélés feltételeit kimutatni. ${ }^{135}$ Ennek a gondolatnak az a rendeltetése, hogy a románság megmaradását a Dunától északra ralószinüvé tegye a barbár népek ádáz támadásai közepetle. Ezt a sort toldja meg újabb szimbiózissal. „Nincsen szó az állam tekintélye alatt újonnan jött és katonai rendeltetésü magyarokról, akik összekeveredtek és megbarátkoztak volna a Kárpátoktól nyugatra esö területek szabad románjaival, hanem egy ösrégi török népességröl ... ${ }^{136}$ amely önállóan maradva, $a$ romiánokkal együft ezekben a ,római" formákban szervezkedett meg, amelyekhez késöbb ugyanennek a románságnak népies jellegü politikai alkotásai járultak. Tehát a székelyekkel szimbiozisban, vagyis együttélésben vagyunk: " magyarokkal csak szomszédságban. A különbség lényeges."137

Világosnak és indokoltnak igazán nem nevezhető ez a tétel. Eleitől végig többé-kevésbbé ötletes, de talajtalan történelmi spekuláció, amelynek valóságértéke nincsen. Felépitését szerzője nemzeti vágyai határozzák meś és ezek a románság folytonosságának és korai politikai kikristályosodási pontjainak irányába feszülnek. A fejedelemségek megszervezése elötti időkbe helyezett képzelt állam-embriók sora gazdagodott egy újabb, ezúttal erdélyi Bomániával. A szerkezet tartóoszlopai felettébb gyengék. A románság székelyföldi jelenlétét a tárgyalt korban semmi sem bizonyitja, politikai szervezetéröl beszélni, a legcsekélyebb forrás híján, felesleges játék. Ennek a képzelt románságnak képzelt együttéléséröl beszélni a szintén képzelt török néppel, amelyik a székely öse lett volna, szintén nem tartozik a megalapozott dolgok közé. Semmi adat arról, hogy honnan, mikor, milyen körülmények között került volna a Kárpátok két oldalára ez az ismeretlen török nép. Vagy Iorga visszatért volna a hún eredet feltevésére? Mivel foglalkozott,

131 I. m. 7.

132 Vö. Iorga: Ist. Rom. II, 108-9., La place des Roumains. Bue., 1935 I, 90.

133 Ist. R. II, 107.

134 Consid., 8.; Ist. R. II, 109.; La place des R. I, 90-1.

135 Consid., 8.

136 Vö. Ist. R. III, $29-30,34,50-7$.

137 Ennek tulajdonítja Iorga a Cselló (Ceahlău), Ráró stb. hegynevek szerzöségét. 
milyen volt a nyelve, milyen volt az életformája ennek a rejtelmes török népnek, amelyet a német lovagrendnek kellett rolna letelepítenie? ${ }^{128}$ Azután miért nem a régebben ott lakó és számosabb román népet szervezte meg katonailag a rend? Miért került felül a székely, mikor a románság ajándékozta meg politikai szervezettel a székely népet? A kérdések egész özönét zúdíthatnók Iorga új ötlet-szövedéke felé, de erre nincsen szükség. mert a puszta feltevésekkel a történettudománynak dolga nem lehet. A szerzö számára az volt fontos, hogy a székelyek és a magyarok közti szoros kapcsolatot tagadja és hogy a székelyek elrománositására újabb szellemi támpontot nyujtson. ${ }^{139}$ Iorga romantikusan túlfütött nemzeti érzése valószinűvé teszi, hogy tételét meggyözödéssel fogalmazta meg. Végeredményben azért elöbbi gyakran ráltozłatott nézeteinél most sem tudott elfogadhatóbbat nyújtani. ${ }^{140}$

Annak a munkának a nagyobb felét, amelynek célja volt bebizonyítani a román közvéleménynek, hogy a románságnak a Székelyföldön nemcsak múltja, hanem jövöje is van, a román történettudomány vállal'a. Meg kell állapítanunk azonban, hogy nem a román történészek élgárdája vállal. kozott erre. ${ }^{140 \mathrm{a}} \mathrm{A}$ fenti seregszemle meggyözhetett bennünket, hogy a vállalkozók erejükön felüli terhet vettek vállaikra. A nehézségek többfélék voltak. Először is nem rendelkeztek megfelelö középkori forrásokkal. $\mathrm{Ha}$ a székelyföldi románságról a XIV. és XV. századból való nóhány tənúság'ételt elfogadhatónak is itélnök, a folytonosság kérdése igy sem lenne bebizonyítva. A XV. századtól kezdve kétségtelen bizonvos számú román pásztorság, zsellérség és jobhágyság létezése székely területen, de ezek az elemek, akár Erdélyből, akár Havaselvéröl, akár Moldvából jöt'ek, bizonyosan bevándorolt elemek roltak. Abban az ütemben, ahogyan a XV. század vége óta az ösi székely társadelmi és jogállapot fokozatosan elporlik, úgv nö meg a mozgékony, vándorlásra hajlamos román népelemek lehetösége arra, hogy a támadt réseken refurakodjék a székely székek területére. A jelenség mér'ékével csak részletesebb, a jövöhen elvégzendö település- és társada'omtörténeti kutalás fog bennünket megismertetni. Nem szól a székelvföldi román ösiség mellett a helvnevek tanúsága sem. A helvnév̊nvagnak a román elem csak igen csekély részét teszi ki és ami belöle valóban román jellegü, annak fiafalságát legtöbb esetben könnven he lehet bizonyitani. Jel!emző, hogy a románoktól ősi román településnek tartott Oláhfalunak, Galambfalvának stb. nincs román neve, ilyet vagy a magyar névből alakítotfak a helyi románok, (kik betelepülök voltak és így ősi román nevet, mert ilyen nem is volt, nem örizhettek meg), vagy a román uralom idején közigazgatási úton, rendszerint egyszerü fordítás vagy kitalálás útján nyer-

138 Consid., 9. - Az elöadás utolsó mondatában Iorga késznek nyilatkozik vitázni tátele felett. Niưs róla tudomásom, hogy magyar részröl felvették volñ a keztyüt.

139 Giurescu C. C. (Ist. Rom. Buc., 1935. I 277.) Popa-Lisseanu nyomán röviden emlékezik meg a románokrak a székelyekre tett hatásáról.

140 Vö. La place des $R$. I, 149.

${ }^{140}$ 's A székely rovásírást Iorga besenyö, vagy még inkább kún átvételnek minösiti, Ist. $k$. III, 34 . 
tek. ${ }^{141}$ A mesterkélt és ügyellen névadás nem egyszer humoros eredményre vezetett $^{142}$ és még román részröl is kemény bírálatban részesült. ${ }^{143}$ Sok sikere a földrajzi spekulációral próbálkozó kutatóknak sem lehetelt a székelység létjogosultságának tagadásában. A mai székely nép magyar jellegének kétségbevonása egyenesen gyermekes elvakultság és a legszembetünöbb tárgyi tények semmibevevése. Kétségtelen, hogy a székely beszédben, szokásokban, életformában, a néprajz keretébe tartozó tények sorában nem egy a románnal megegyezö vonást találhalunk fel, de ezek távolról sem mutatnak román népi eredetre, hanem egyszerüen egy hosszas, évszázadokra terjedö egymás mellett élésnek, néhol összekeveredésnek legtermészetesebb következményei. A jelenség lávolról sem egyoldalú, nem mindig a román volt a kölcsönzö, a halás természetesen kölcsönös. ${ }^{144}$ A székelyromán népi kölcsönhatás kérdése tárgyilagos és elfogulatlan kutatóra vár.

A Székelyföldön otthonra lelö román népelem pontos számarányát nem tudjuk meghatározni. Annyi bizonyos, hogv a felületes általánosságban mozğó román vélemények valóságértéke egvenlö a semmivel. Ha hitelt adhatunk a Bucov-féle összeirásnak (1760), akkor a négy székelv megve területén 426 községben összesen 5402 román vallású család volt található. ${ }^{145}$ Ezeket mind románnak tekintve (ami kétségen kívül erős túlzás, mert a székelység beolvasztó ereje, illetöleg vonzása sokhelyt eleitöl fogva érvényesült), családonkint - Popa-Lisseanu nvomán - 5 tagot számítva, a székelyföldi románság létszáma 27.010 lélekre volna tehető. Egy másik forrás (1767) 7 szabad oláhı (liberi Valachi) és 51 román pəpi családot jelez. ${ }^{146} \mathrm{Ha}$ azt is figyelembe vesszük, hogy ugyanebben az idöben az egész Székelyföldön mintegy 37.000 család élt, ${ }^{147}$ akkor a két román felekezethez tartozó lakosok arányszáma $14.6 \%$ és a magvar felekezetekhez tarłozóké $85.4 \%$. A beköltöző románok beolvadása (és nem beolvasztása) természetszerüleg állandóan folyt és ebben nem szükséges semmiféle elnyomatást vagy erőszakot keresni. A társadalmi létra legalacsonvabb fokán álló pásztorc`aládok örömmel igyekezlek felemelkedni gazdáik magasabb társadalmi szintjére, ennek legelsö lépése a külön világot jelentő és keleti életszemléletet tükrözö orthodoxia elhagvása volt. Akik közben görög katolikuєokká lettek, azok megindultak a római katolicizmus felé, az orthodoxok jobbára a református egyház hiveivé váltak. ${ }^{148}$.

141 A két Oláhfaluból (Szentegyházasoláhfalu és Kápolnásoláhfalu) Vłahiță és Căpâl. niţă lett. Opreanu váltig nehezményezte a Vlahiţă elnevezést, mikor szerinte ennek neve minden bizonnyal Româneşti (?) lehetett (Terra Siculorum, 10). Nagygalambfalvát a helyi román papok is mindig magyarul nevezték: 1742: Noghi Garofalo, 1785: Naghi Galomfalo, 1810: N. Galonfalo" (Sulica: i. m. 25-6.).

142 Kénos-ból (= Kínos) téves fordítással Sulfureni lett (Sulfur $=$ kén); Késöbb Chinuşu lett a neve.

iłs Ghibedea, V.: Românizarea numirilor de sate in Secuime. Secuimea, 1934. márc. 29.

144 Moldvai román oklevelekben sok magyar eredetü magyar szót lehet találni, pl. marha, marfa $=$ marha ciurda $=$ esorda; poştea-meşteru = postamester; Iorga: Acte româneşti din Ardeal, Buc. 1916, 257. Alişverişulu \pm adás-vevés. Uo. 205. stb.

145 Anuarul Inst. de Ist. Nat. Cluj, III, 1924/25 nyomán Popa-Lisseanu: Sieules el Roumains. 2. kiad. Buc., 1939, 65-78.

: +6.7 Berlász J.: i. m. 240 (Melléklet).

145 Vö. fentebb. 
De már hamarabb is folyt egyes vidéktken a heolıadás. I társadalmilag emelkedni akaró romảnok számára sokkal inkább meg volt a lehetösége a székelység jogi keretei közé való behatolásra és a székely elöjogokban való részesülésre, semmint azt általában gondolni szokás. Román nevet viselö székelyek már a XVI. században sem tartoztak a ritkaságok közé. Amióta románság volt a székelységen, a beolvadás a legesekélyebb kényszer nélkül szünteleniil folyt. Persze nemcsak a székelység hódiłott, megtette ęzt több helyen, igy Marosøzéken maga a románsảg is. Nincs igazuk a román szerzőknek, amikor az asszimilációs folyamatot egyoldalúan, csak a románság rơására történönek mulatjảk be. Még inkább lévednek, amikor eröszaknak, nemzetiségi politika eredményének tulajdonitják a románság térvesztését. Ha ez így lett volna, nem vesztette volna el a magyarság hatalmas számban fiait Erdélyszerte épen a kiegyezés korában. A székelyföldi románság fogyása egyébként is jóval megelözi a modern értelemben vett nacionalizmus és nemzetiségi kérdés korát.

A beolvadási folyamatot jelzi a XVIII. század végén G. T. D. Gróf Teleki Domokos) útleirása. A háromszéki románokról megemliti, hogy elfelejtik nyelvüket, amit inkább csak pópáik beszélnek még, de vallásukat hüségesen megörizik. Azt is megfigveli, hogy ezek a magyarosodó romúnok ilem olyan vadak és bárdolatlanok, mint más vidékek románjai. ${ }^{149}$ Dós Elek erdélyi útinaplója (1821) is öriz meg részleteket a székelyföldi románokról. İgy például Bikszádot, ,,mely egészen a G. Mikó Miklósé, oláhok és Magyarok lakják, de az oláhok is inkább Magyarul beszélnek"..150 Eb’öl a községböl nemsokára teljesen kiveszett a román szó és hasonlóan járt sok más helység. A természetes beolvadás folyamán a két közönségesen románnak ismert felekezet, a görög keleti és a görög katolikus, székelyföldi hívei sorában mind több és több lett a magyar anyanyelvü. A beolvadást sürgetö magyar magalartásra a XIX. század harmincas-negyvenes éveinél hamarább egyállalán nem kerïlhetett sor és valójában elemi erövel csak 1848-ban tört ki a két fajta közötti rersengés, de akkor sem a Székelyföld belsö területén. Az abszolutizmus idején (1857) a román vallásúak száma 60.524, a magyar vallásúaké 322.882 volt és ez az arány az 1910-i népszámlálás adatai szerint 84.270 és 442.676 volt. Másszóval kifejezve, a fenti 53 év alatt az egész Székelyföldön a román vallásúak jobban szaporodtak $(39.2 \%)$ mint a magyar vallásuak $(37 \%)$ ! Söt: összehasonlítva az. 1761-i viszonyokkal is aránylag esekély a román valásúak számbeli visszaesése. A román vallást követök és a magukat román anyanvelvïeknek valló lakosok aránya 1891-ben $116.425-97.200$ és 1910-ben $138.763-114.027$ lélek. ${ }^{151}$ Abszolut értékhen kifejezve a fenti két idöpont közt csak Udvarhely megyében csökkent a román vallásúak és anyanvelvűek száma, a másik

149 Egynehćny hazai utazások le-írása ... Bées 1796. - Vó. Ilie Dăìnu cikkết a Glas Rom. în reg. sec. 1936. ápr. 10. sz..ban: Călătoridie qnui magnat prît Secuime in 17.94 .

150 Az Erd. Múz. Kézirattára 1874. sz. 8.

151 Szilagyi Olivér: A székelyföldi görög keleti és görög katolikus vallású lakosság az 1857-i és 1910_i népszámlálások tükrében. Magyar Kisebbsốg 1938, 46. - Háromszék megyében 1900-ban volt $85,1 \%$ magyar és 14,2\% román, 1910-ben 83,4\% magyar és $15,5 \%$ román. Tehát a románság itt tért nyert, nemhogy eltünöben lett volna. (I. m. 52.). 
három székely megyében, különösen Csíkban és Háromszéken, elörehaladást tett a román elem. Indokolatlan ezek szerint a román szerzök panasza, mintha fajtestréreik száma rohamosan csökkent rolna az 1867. utáni korszakban. A tizes évek és a világháború ideje alatt már kedrezötlenebb volt a helyzet és az 1916-i román hetörés visszahatása sok román felekezetii székelyt késztetelt áttérni valamelyik magyar felekezetre. Az önkéntes magyarosodás olyan elörehaladott fokon volt (a nyelvi heolvadáson már régen túljutott), hogy az utolsó lépés, a vallásváltoztatás megtevésére megvolt a hajlandóság, még a román uralom beköszöntése ulán is. ${ }^{152}$ A folyamat érettségének köszönhetö, hogy a háború után a helyzet nem fordult meg és a román cikkírók sokszor méltán fejezhették ki emiatt elégedetlensé güket. A gyergyai görög katolikus esperességnek 1911-ben 22.000, 1923-ban már csak 17.000 híve volt; az udvarhelvinek 1911-ben 3807, 1923-ban $2255 .{ }^{153}$ A román uralom idején megindítolt ú. n. visszarománosítási mozgalom ért el itt-ott valamelyes helyi sikert, de lényegében a beolvadási folyamatot legfeljebb megállítani tudta, ezt se mindenütt, de nem egyúttal meg is forditani. A magyar visszatérés a székelyföldi román kérdésben ismét üj helyzetet teremtett. A megtévelyedettek és megriadtak tömeges visszatérése mutatja, hogy a kérdés régkifejlésével állunk szemben. A székelyföldi románság beolvadásának dereka egyébiránt olyan régen meg. történt, hogy a magyar társadalomnak a román eredetủekkel szemben általánosan tanúsitott tartózkodása itt meg sem található. A görög keleti vagy görög katolikus székely, aki esetleg még román nevet is visel, semmiképen sem volna meggyözhetö arról, hogy ösei románok leftek volna, söt az ilyen gyanúsitást a legsúlyosabb sértésként fogja fel. Az elmondottakból annyi kitünik, hogy a székelyföldi románság jórészének beolvadása egy már teljesen megérett folyamat, melynek visszafordításától, vagy bármi más bonyodalomtól tartani a mai körülmények közt gondolni sem lehet. Ez egyúttal arra is rávilágit, hogy milyen rövidlátó és milyen reménytelen volt a román történeltudósok igvekezete a székelység multjának és jelenének nem is annyira vissza-, mint inkáhb elrománositására. A románból lett székelyek száma a tösgyökeres székelyeké mellett aránylag olyan kicsiny, hogy még sikeres visszaalakításuk sem lett volna jelentős román eredmény, és a Székelyföld népi képét távolról sem változtatta volna meg lényegesen. Természetesen a fent vázolt beolvadási folyamalba nem értettük bele azokat a székelyföldi románokat, akik anyanyelvüket és vallásukat egyaránt megörízték. Román anyanyelvüket és görög keleti ragy görög katolikus felekezetïket épúgy bántatlanul megörizhetik, mint román nemzetiséghez tartozásuk tudatát. De a magyar öntudatú, magyar anyanỵelvü, magyar gondolkodásmódí, a magyar nemzet sorsával jóban-

152 Jellegzetes eset történt Abásfalva községben, ahol a görög katolikus rallású, magyar anyanyelvä katonaköteles ifjuság egy tömegben lépett át a református hitre, amikor az új urak 1919-ben a vörösök elleni harera besorozták óket. A román katonai hatósáook ekkor rsak románokat soroztak, de románoknak tekintettek minden görög katolikus vallású egyént. Az abúsfalri legények áttérésükkel a magyar nemzet iránti hüségüket fejezték ki. L. Riînvierea. 1938. jan.-máre. 51-2.

153 Opreanu: Săcuizarea Românilor prin religie. 35 . 
rosszban osztozó görög katolikus és görög keleti székelyek, bármilyen lett légyen is távoli népi eredetük, minden kényszer és csábítás nélkül magyarok, mert azok akarnak és mások nem is tudnak lenni. ${ }^{154}$

6.

A székely-román kérdés felvetése az elsö világháború utản szoros összefüggésben volt a székelység földrajzi elhelyezkedésével az új román állam közepén. Az idegen székely elem tövis volt az állam testében; ezt sürgősen el akarlák távolítani. A feladat nemesak az állami intézkedések vonalán jelentkezett. A román társadalom is szïkségesnek tartotta a keleterdélyi népiségi helyezeten javítani. Vidéken közvetlen megfigyeléseken alapuló tapasztalatok, némi egyházi hagyomány a székelyföldi románnak maradt románság közepette, régül Iorga kezdeményezései szolgáltak alapjául a meginduló történelmi, néprajzi, földrajzi, fajbiológiai stb. kutatásoknak. Mind többen és többen érezték szükségét, hogy a kérdéshez román részröl hozzászóljanak. Iorga egyéni kérdéséböl elöbb a tudósok, azután az újságírók, tanárok, papok és más értelmiségi elemek kérdése lett, végül a folyamat beletorkollott az egyelemes román közvéleménybe, hogy a harmincas érek második felében kifejezetten államüggyé fejlödjék. Ennek a folyamatnak részleteit más vonatkozásban vizsgálom meg. Most megelégedtem azzal, hogy beletekinleltem a székely-román kérdés román történeti irodalmának kevéssé ismert bozótjába. A kérdések megoldására sem törekedtem, mert meggyőződésem szerint ezt nem cáfolattaI, hanem az egyes kérdésrészlelek rendszeres feldolgozásával kell elvégezni. A romáu történetírás a maga célkitüzéseit elöbb a nemzeti közvéleményben, azután - részben - a nemzetköziben is megpróhálta valóra váltani. Függetlenül a valóságtól, az állami és nemzeti érdekeknek állt feltétel nélkuili szolgálatába. Tanításai röviden a következökben foghatók össze:

1. A székely és a magyar két egvmástól különbözö nép.

2. A Székelyföld nem földrajzi egység és csak Romániával egvütt logikus összefüggésü földdarab.

3. A Székelyföld népiségileg nem egységes; a székely keverék nép, benne a román elem a tulnyomó.

4. A székely föld és nép múltja nem a magyar, hanem a román nép történetének egyik fejezete.

5. A székely nép lelki és testi alkata, néprajza, müvészete, létformája jórészt azonos a román népével.

A székelység idegen testét a román nép természetes asszimiláció útján nem volt képes eltüntetni. Ellenkezöleg, a Székelyföldön éppen a románság volt kitéve a beolvadás veszedelmének. Kapóra jött azonban az a tény, hogy a székelységbe évszázadok óta bizonyos mennyiségü román vér keveredett. A nagyjából megállapítható tényállást kellett csak módfelett felnagyítani és felhasználni a nemzeti közvélemény megnyerésére. İgy lett nem várt nagy jövője Iorga régi gondolatának.

A román történettudomány fáradozásai a székely-román viszony kér 
désében a székely kérdésnek egy új, eddig kevéssé méltatott részletét nozták elötérbe: a népiségtörténetét. Foglalkoznunk kell — még pedig sürgősen - a Székelyföld népiségtörténetével is. Csak mostanság kezdünk belelátni a szenvedésnek, a mellőztetésnek, az elnyomatásnak abba a rettenetes zürzavarába, amely a székely nép történelmi életét jelentette. Üjabban sok jel mutat arra, hogy a magyar tudományosság felismerte nagy feladatait a székely múlt felkutalásában. Remélhetö, hogy a történészek, régészek, jogászok, néprajzosok, nyelvészek, társadalomkutatók, közgazdászok és más szakemberek egyberetett munkája a székely valóság megismerésének hamarosan új és virágzó korszakát nyitja meg. 